\title{
The Green Investment Report
}

The ways and means to

unlock private finance for

green growth

A Report of the Green Growth Action Alliance

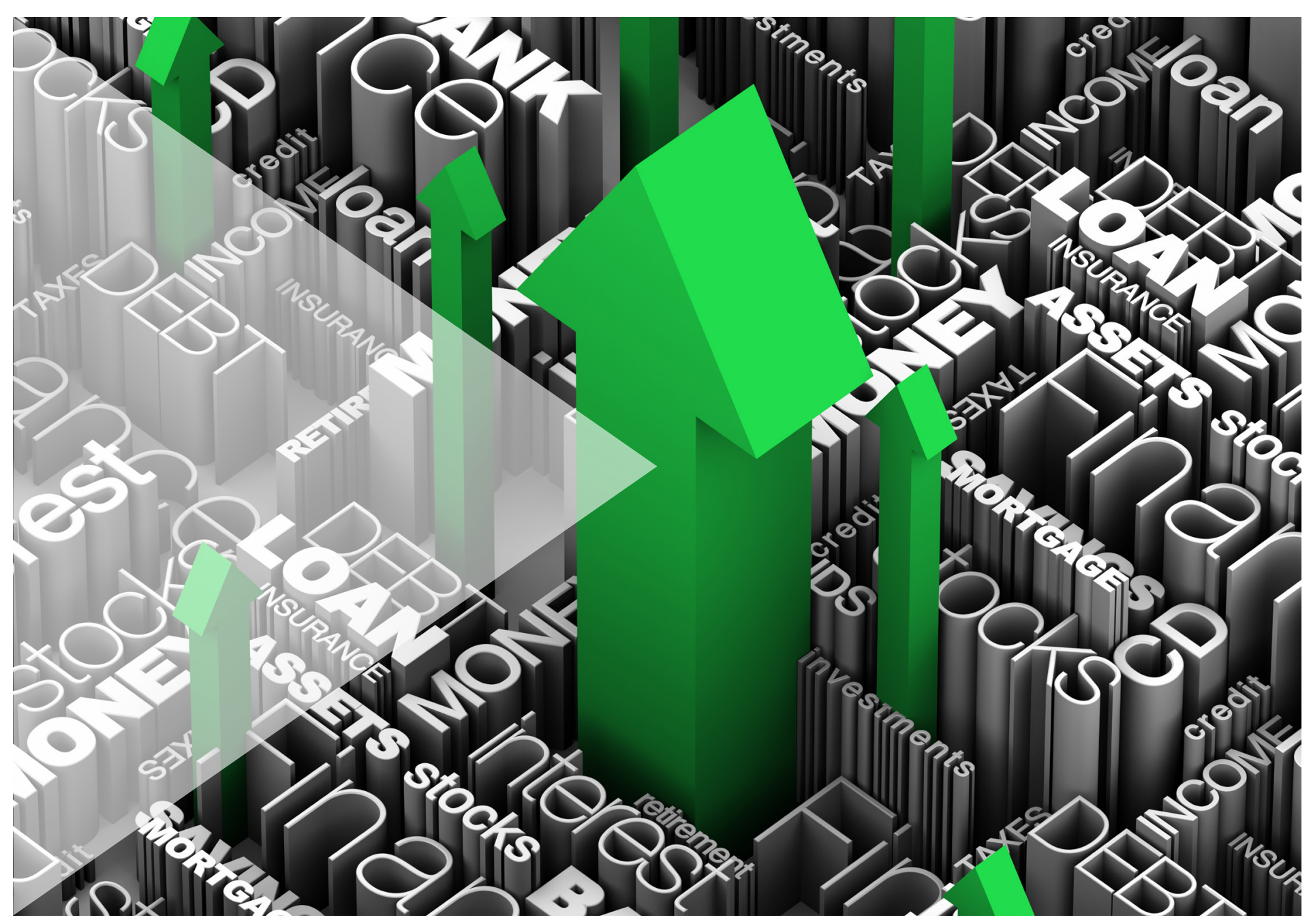




\section{Acknowledgements}

The World Economic Forum wishes to thank all members of the Green Growth Action Alliance for their leadership and contributing time, data, case studies and opinions. These contributions form the core of this report. The Forum would also like to thank its knowledge partner Accenture, who synthesized and developed the content, and Simon Zadek, who provided guidance in his capacity as an advisor to the World Economic Forum on sustainability issues and Senior Fellow of the Global Green Growth Institute.

\section{accenture}

High performance. Delivered.

The authors would like to specifically thank the following organizations that provided expert guidance, case

studies, research and data, without which this report would not have been possible:

- Bloomberg New Energy Finance

- Climate Policy Initiative

- Global Green Growth Institute

- International Energy Agency

- OECD

- The World Bank

- World Resources Institute

The following organizations have also provided expert guidance for the report:

- Brookings Institute

- Overseas Development Institute

- United Nations Environment Programme

- UNEP Finance Initiative

\section{Disclaimer}

The viewpoints expressed in this report attempt to reflect the collective engagement of individuals as Green Growth Action Alliance members and do not necessarily imply an agreed position among them or institutional endorsement by any participating company, institution or organization involved in the Alliance, or of the World Economic Forum.

\section{World Economic Forum}

Geneva

Copyright (C) 2013 by the World Economic Forum

Published by World Economic Forum, Geneva

Switzerland, 2013

www.weforum.org

All rights reserved. No part of this publication may be reproduced, stored in a retrieval system, or transmitted, in any form or by any means, electronic, mechanical, photocopying, or otherwise without the prior permission of the World Economic Forum.

ISBN-13: 92-95044-65-7 / 978-92-95044-65-4

World Economic Forum 91-93 route de la Capite $\mathrm{CH}-1223$ Cologny/Geneva Switzerland 


\section{Contents}

2 Acknowledgements

4 Foreword

5 Preface

6 Executive Summary

9 Introduction

11 Part 1: Green Investment: Current Flows and Future Needs

18 Part 2: Unlocking Private Finance

25 Part 3: Catalysing Leadership and Private Investment

27 Appendices

38 References 


\section{Foreword}

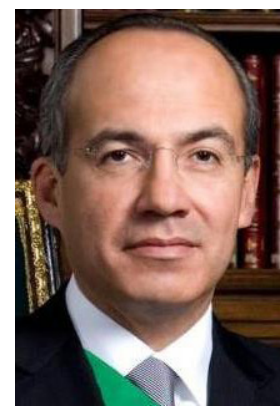

Felipe Calderón, Chair, Green Growth Action Alliance
Shaping a global economy fit for the 21st century is our greatest challenge. Such an economy in 2050 will satisfy the needs of more than 9 billion people, who will rightly demand equal opportunities for development. Delivering such inclusive development in a sustainable way, however, requires that we remain within the boundaries of what our planet can safely deliver. Economic growth and sustainability are inter-dependent, you cannot have one without the other, and greening investment is the pre-requisite to realizing both goals.

Dramatic upgrades in technology, skills, policies and business models, along with an aligned public consciousness, are needed for the transition to a green growth pathway. Infrastructure investment required for sectors such as agriculture, transport, power and water under current growth projections stands at about US\$ 5 trillion per year to 2020. This 'business-as-usual' investment will not lead to a stable future, however, unless it achieves environmental and sustainability goals. This development needs to be greened by re-evaluating investment priorities, building capacity, investment-grade policies and improving governance, among other activities. Additional investment needed to meet the climate challenge-for clean energy infrastructure, sustainable transport, energy efficiency and forestry-is about US\$ 0.7 trillion per year.

Private financiers see these massive investment requirements as an opportunity Today, we see major growth in clean energy investment, with financial flows worldwide approaching those in carbonintensive energy sources. Further, developing countries are proving an increasingly important source of capital. Since 2007, clean energy investment originating from outside the Organisation for Economic Co-operation and Development (OECD) grew at 27\% per year compared with $10 \%$ per year from OECD countries, albeit from a far lower base.

Yet today, despite signs of increasing private finance into clean energy and other green investments, there remains a considerable shortfall in investment. Closing this gap is our collective task and one that we cannot afford to fail.
Public finance, linked to smart, enabling policies, has a critical role to play. Given the scarcity of public funds, governments' contributions to closing the gap will depend on their effectiveness in mobilizing private investment. Experience demonstrates this is possible when supported by targeted financing mechanisms and institutional arrangements that blend private and public interests, expertise and resources to reduce risk and address bottlenecks preventing private investment.

The Green Growth Action Alliance was created to accelerate this agenda at the 2012 G20 Summit in Los Cabos, Mexico. The Alliance's vision, one that I share and actively promote as its founding chair, is to drive greater investment in green growth by unlocking potential sources of finance. Collaboration between business, governments, civil society and international organizations in overcoming barriers to and securing the benefits of green growth is the DNA of the Alliance's approach.

The Green Investment Report is the first report of the Alliance. It aims to inform and inspire policy-makers and public and private finance providers to close the gap in delivering inclusive, sustainable growth. It is the first time that a number of important institutions have joined to deliver a powerful message about the scale of the green investment gap that must be filled, and to spell out the ways and means to address the gap in green infrastructure investment. I appreciate this collective effort and would like to thank, in particular, Bloomberg New Energy Finance, the Climate Policy Initiative, the Global Green Growth Institute, the International Energy Agency, the OECD, the United Nations Environment Programme, the World Bank Group and the World Resources Institute for providing data, analysis, case studies and other support that enabled us to produce this report. I would also like to thank and congratulate the World Economic Forum for coordinating the whole effort and producing this report.

The Green Investment Report is one of many ways in which the Alliance is advancing green growth. Its members are collaborating on initiatives that aim to prove the efficacy of financing green growth, from energy efficiency to renewable energy and climate-smart agriculture. It is, as the name states, an alliance for action. I invite G20 governments, public finance institutions, investors and policy-makers to read this report and join us in leading the way to making a difference. 


\section{Preface}

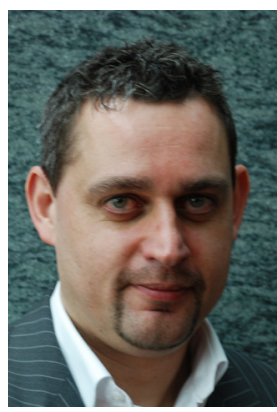

Dominic Waughray, Senior Director, Environmental Initiatives

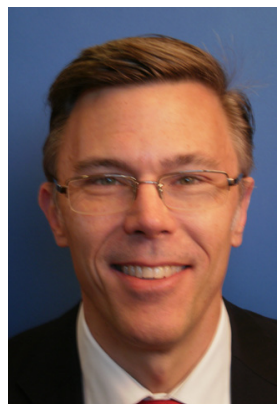

Thomas Kerr,

Director, Climate Change and Green Growth

Initiatives
We live in an age of increasingly complex global challenges that mandate new approaches. As we witness the combined-and increasingly inter-related-challenges of the global economic crisis and the climate change crisis, we also witness the need for new forms of both dynamic and resilient global leadership to solve these challenges, using innovative, multistakeholder approaches. Arguably, mobilising the required scale of green investment lies at the core of the combined global economic and climate challenge and demands new such approaches for triggering action. This makes it a pertinent agenda for the World Economic Forum. Since receiving an invitation to create the 2009 G20 multistakeholder Task Force on Low Carbon Prosperity, the Forum has been delighted to support its members and stakeholders to trigger public-private innovation in this space, including the 2010 Critical Mass Climate Finance Initiative with the United Nations Foundation and the International Finance Corporation, supported by various institutional investor groups; and support to the 2011 Green Growth "Business 20" (B20) Task Force for the French G20 Chair. From its investor community, the Forum also ran a successful series of complementary Green Investment Reports, 2009-2011, reporting on the state of the global clean energy investment agenda.

During 2012, the World Economic Forum brought together these various workstreams to assist the Mexican G20 Chair with a series of refreshed B20 Task Forces that provided guidance and input to the G20 Summit in Los Cabos, including a Task Force on Green Growth. The Green Growth Task Force brought together for the first time leading public finance agencies, private investors, infrastructure and agriculture companies, and inter-and non-governmental organizations, with a specific focus to set recommendations for green growth. Task Force members took the decision to supplement their set of G20 recommendations with an offer to launch the Green Growth Action Alliance, a practical vehicle for action with a clear mission to advance the green investment agenda and to report on progress to the G20.

The World Economic Forum is honoured to serve as the Secretariat of the Green Growth Action Alliance, and to help its members to achieve impact through advancing new solutions, engaging a wider set of public and private finance providers, and providing workable models on finance to existing platforms and institutions such as the United Nations Framework Convention on Climate Change, the United Nations Sustainable Energy for All Initiative, the World Bank Group, the International Development Finance Club, the Global Green Growth Institute, and the Global Investor Coalition on Climate Change.

The Alliance now counts nearly 60 members collaborating to identify ways that limited public funds and public policies can be targeted to unlock and scale up private-sector investment, through identifying innovative financing and de-risking structures, supporting pilot-testing of new models in key regions, and feeding results into international processes. We hope this first report will provide a blueprint for action that government, business and civil society leaders can use to transform the global economy to an economically and environmentally sustainable pathway. We look forward to reporting on our progress in the future. 


\section{Executive Summary}

Greening global economic growth is the only way to satisfy the needs of today's population and up to 9 billion people by 2050 , driving development and well-being while reducing greenhouse gas emissions and increasing natural resource productivity.

\section{Considerable progress has been made in transitioning to} green growth. Global investment in renewable energy in 2011 hit another record; up 17\% on 2010 to US\$ 257 billion. This represented a six-fold increase from 2004 and was 93\% higher than in 2007, the year before the global financial crisis. Global agricultural productivity growth rates are exceeding overall population growth rates, and since 1990, more than 2 billion people have gained access to improved drinking water sources. Energy efficiency is widely recognized as providing economic opportunities and improved environmental security, while the fuel efficiency of vehicles has more than doubled since the 1970s.

Developing countries are playing a growing role in scaling up green investment. Cross-border and domestic investment originating from non-OECD countries grew 15-fold between 2004 and 2011 at a rate of $47 \%$ per year (compared with 27\% per year for OECD-originating investment), albeit from a low base. Clean-energy asset financing originating from developing countries in 2012 is on track for the first time to exceed those originating from developed countries. This investment is due in part to the creation of green growth strategies by a number of developing country governments - to advance water resources, sustainable agriculture, and clean energy. Developing country public finance agencies can accelerate this trend by targeting more of their funds to leverage private finance.

Figure i: The evolution of global new asset finance flows for clean energy (US\$ billions)

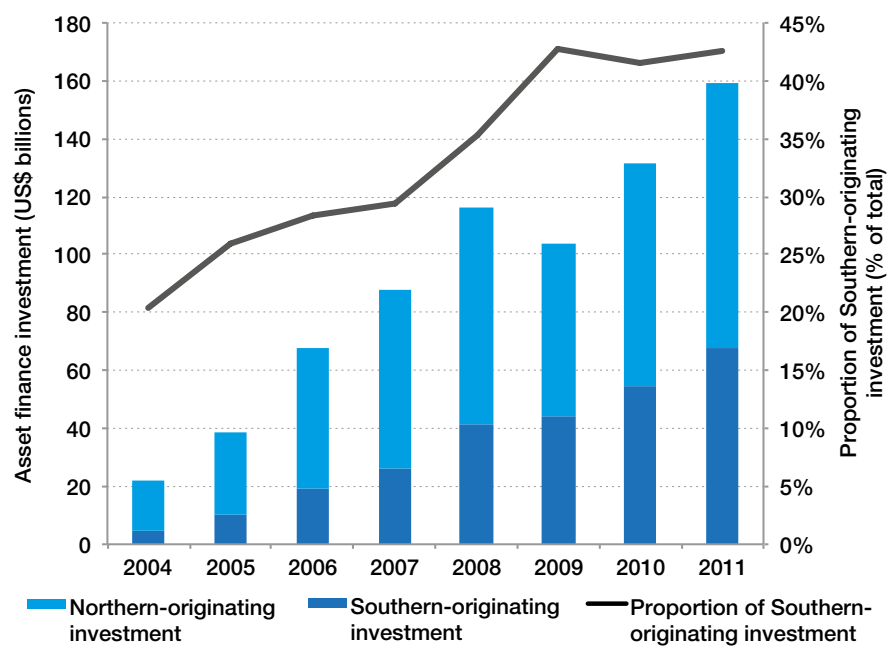

Note: Data includes new-build asset finance only. Source: Bloomberg New Energy Finance'
Such progress, however, remains inadequate. Progress in green investment continues to be outpaced by investment in fossil-fuel intensive, inefficient infrastructure. As a result, greenhouse gas levels are rising amid growing concerns that the world is moving beyond the point at which global warming can be contained within safe limits. A recently published World Bank report warns that the world is on track for a global average temperature increase of at least $4^{\circ} \mathrm{C}$ above pre-industrial levels, bringing further extreme heat-waves, hurricanes and lifethreatening rises in sea levels. Natural resource productivity is not increasing quickly enough to stem the depletion of critical resources, notably water and forests. Soil erosion is accelerating and fish stocks are declining precipitously. Such trends, combined with growing climatic instability, are driving up commodity prices, threatening food security in a growing number of communities.

Significant barriers exist to securing the required scale and pace of progress. The continuing global economic crisis has dimmed longer-term outlooks by business and governments. Financing for much-needed infrastructure is constrained by limits in public finance, policy and market uncertainty and the unintended consequences of financial market reform. Legacy fiscal measures such as fossil-fuel subsidies combine with the slow progress of international climate negotiations to weaken market signals that might otherwise incentivize green investment. Lack of awareness of private finance providers of green growth opportunities and continued investment in fossil-based resources are restricting progress.

Greening investment at scale is a precondition for achieving sustainable growth. The investment required for the water, agriculture, telecoms, power, transport, buildings, industrial and forestry sectors, according to current growth projections, stands at about US $\$ 5$ trillion per year to 2020. Such business-as-usual investment will not deliver stable growth and prosperity. New kinds of investments are needed that also achieve sustainability goals. Beyond the known infrastructure investment barriers and constraints, the challenge will be to enable an unprecedented shift in long-term investment from conventional to green alternatives to avoid locking in less efficient, emissions-intensive technologies for decades to come.

Taking the power sector as an example, investment in fossil-fuel intensive infrastructure is increasing annually and is higher than clean-energy investment. The International Energy Agency (IEA) predicts that an unprecedented long-term shift in investment over the next few decades from fossil fuels towards a cleaner energy portfolio is needed to avoid dangerous climate change. This is achievable by re-evaluating investment priorities, shifting incentives, building capacity, investment-grade policies and improving governance. 
Figure ii: Conceptual assessment framework

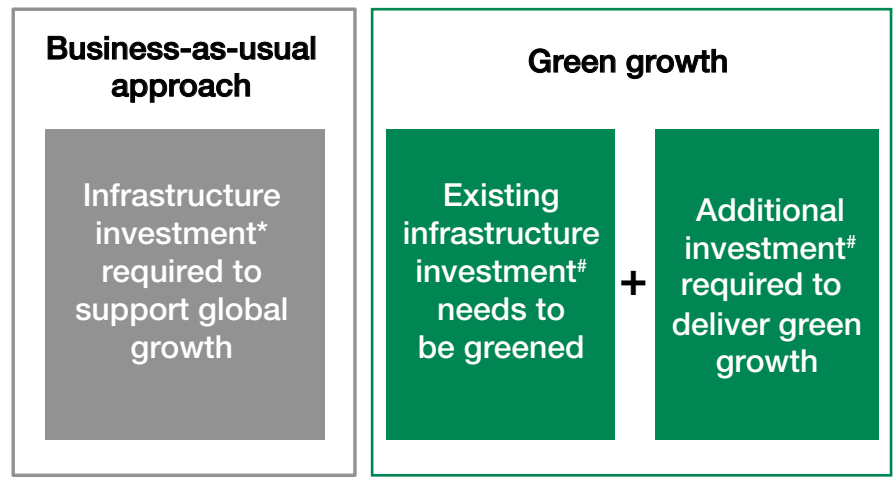

Transition

\section{Enabling policy conditions, tools, mechanisms and instruments}

Notes: *Sectors assessed include water, agriculture, forestry, telecommunications, transport, power, buildings and industry. ^ Quantity of business-as-usual investment that needs to be 'greened' is not assessed. \#Sectors assessed limited to transport vehicles, power, industry, buildings and forestry.

There are additional, incremental investment needs of at least US\$ 0.7 trillion per year to meet the climate-change challenge. This investment is needed for clean energy infrastructure, low-carbon transport, energy efficiency and forestry to limit the global average temperature increase to $2^{\circ} \mathrm{C}$ above pre-industrial levels. While the IEA predicts that corresponding fuel savings will more than compensate for these investment needs, there are significant policy, market and financial barriers preventing business from taking advantage of these profitable investments. Additional investment needed to support green growth, beyond business-as-usual spending, in other sectors such as agriculture and water is not well known; further analysis is needed to better understand the full set of green investment needs across these areas.

Figure iii: Total estimated investment requirements under business as usual and estimated additional costs under a $2^{\circ} \mathrm{C}$ scenario

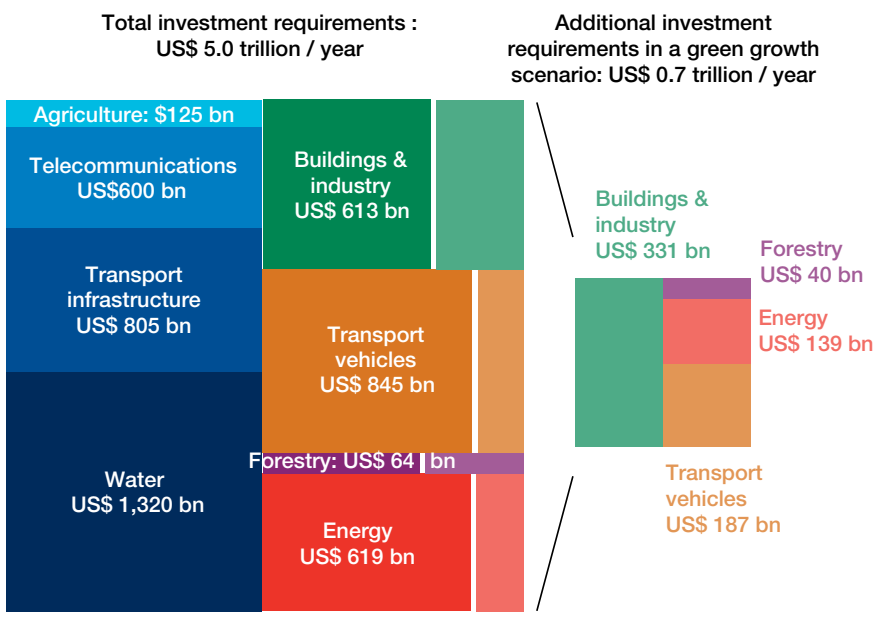

Investment that needs to be 'greened'

Sources: OECD 2,3, IEA4, Food and Agriculture Organization of the United Nations (FAO) ${ }^{5}$, United Nations Environment Programme (UNEP) ${ }^{6}$

Note: All data converted to $\$ 2010$ equivalents
Closing the green investment gap is affordable but needs to be supported by effective public policy. Public resources are limited, especially during the current period of austerity measures across much of the OECD. Therefore, reliance on public-sector investment must be minimised, and more attention paid to attracting private finance, which is at the core of the green growth transition. Assets being managed in the OECD amount to US\$ 71 trillion; but deploying these assets toward green infrastructure is limited by policy distortions and uncertainties, market and technology risks, and reinforced by the reluctance of investors to take a longer-term view.

Experience demonstrates the potential for closing the green investment gap by mobilizing private finance through the smart use of limited public finance. Evidence from climatespecific investment illustrates that the targeted use of public finance can scale up private financial flows into green investment through measures such as guarantees, insurance products and incentives, combined with the right policy support.

While leverage ratios are difficult to compare across projects, countries and instruments, ratios of 1:5 and above are not uncommon, and there are some cases of instruments-such as grants-delivering much higher ratios. There is strong potential for increased lending, advancing and rolling out de-risking instruments, using carbon credit revenues, and targeting grant money combined with technical assistance to attract much greater private investment.

The green investment gap can be addressed through the use of such instruments. If public-sector investment can be increased to US\$130 billion and be more effectively targeted, it could mobilize private capital in the range of US $\$ 570$ billion. This would come close to achieving the US\$ 0.7 trillion of incremental investment required to move the world onto a green growth pathway. However, greening the remaining US\$ 5 trillion in infrastructure investment will remain a major challenge requiring policy reform and a stronger push toward investment-grade policy.

Figure iv: Potential public-private finance mobilization to close the cost gap for climate-specific investment

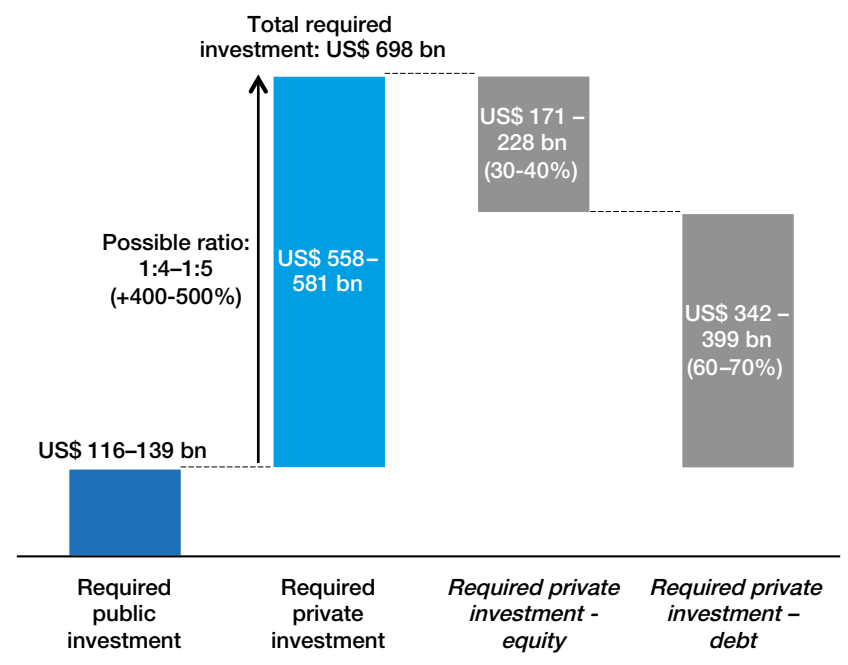

Note: The debt-to-equity ratio is assumed at 70:30 based on the current average debt to equity ratio of clean energy projects 
Leadership by governments, international financial institutions and private investors is needed to address the green

investment gap. This first Green Investment report includes four recommendations that, if understood and acted on, could address the gap in green investment:

1. Greening investment, and thereby the economy, is the only option. Building from the 2012 G20 Summit, G20 leaders should reaffirm that greening the economy is the only route to sustained growth and development.

2. The transition is financially viable. The incremental costs of greening growth are insignificant compared with the costs of inaction. To accelerate and guide the green growth transformation, governments, investors and international organizations must improve efforts to overcome barriers and improve global tracking, analysis and promotion of green investment.

3. Effective policy pathways and the efficient deployment of public finance to green investment is well understood, tried and tested, and must now be scaled up. The G20 governments must accelerate the phasing-out of fossil-fuel subsidies, enact long-term carbon price signals, enable greater free trade in green technologies, and expand investment in climate adaptation. Investment-grade public policy is an important prerequisite to engage the private sector. Public financial institutions need to more actively engage private investors through scaling up deployment of proven instruments and mechanisms, while also designing new funds and tools to attract private finance for new investment opportunities.

4. Private investors will need to take a new approach to benefit from green investment opportunities. Green infrastructure investment can provide attractive long-term, risk-adjusted returns. Private investors should not wait for perfect public policies to remove any reasonable risk. They can enhance comparative risk analysis of green investment by making greater use of investor forums and engagement with public finance agencies to advance new financing solutions that open up an attractive, sustainable market. 


\section{Introduction}

\section{Meeting global climate and environmental goals will require the greening of growth, while converting existing carbon-intensive}

\section{assets}

The Organisation for Economic Co-operation and Development (OECD) estimates that our current path will add a further 3 billion people in developing countries into the middle classes within 20 years ${ }^{7}$. This will create an unprecedented rise in demand for energy, water, transport, urban development and agricultural infrastructure. Meeting this demand while respecting planetary boundaries will be challenging; under current policies, water use is predicted to increase by $55 \%$ between now and $2050^{\circ}$. Agricultural production will need to double in the same time span, leading to large-scale deforestation unless cultivation practices change. Energy demand, if left unimpeded, will rise by $85 \%$ by $2050^{\circ}$, leading to a $4-6^{\circ} \mathrm{C}$ increase in global average surface temperatures. This will bring further extreme heatwaves, hurricanes and life-threatening rises in sea levels. Damage from Hurricane Sandy alone, which devastated portions of the Caribbean, mid-Atlantic and north-eastern United States in October 2012, is estimated to have cost more than US\$ 60 billion, while more than 250 lives were lost $^{10}$.

Greening growth can alleviate the risks from future climate change and environmental degradation, and progress is being made. In the transport sector, the fuel efficiency of road vehicles has more than doubled since the early $1970 s^{11}$. In 2011, global investment in the renewable energy sector hit another record; up 17\% on 2010 to US\$ 257 billion, a six-fold increase from 2004. Investment was 93\% higher last year than in 2007, the year before the global financial crisis ${ }^{12}$. This growth was driven in part by government policy support that led to rapid decreases in the costs of renewable energy. These policies have come under review due to the current fiscal crisis, however, creating volatility in the global clean-energy markets in the past year. Markets are beginning to consolidate and prices are stabilizing ${ }^{13}$, with the industry showing signs of restructuring.

Further progress has been made in the water and forestry sectors. Since 1990, more than 2 billion people have gained access to improved drinking water sources - an important achievement for one of the Millennium Development Goals - to reduce by half the proportion of people without sustainable access to safe drinking water and basic sanitation ${ }^{14}$. In the forestry sector, the United Nations Environment Programme (UNEP) estimates that more than US\$ 64 billion is invested annually in forest protection and reforestation ${ }^{15}$.
Despite signs of progress, significant barriers still exist to securing the required scale and pace of investment in the transition to green growth. The continuing economic crisis in Europe and the United States, with its rippling global impacts, discourages business and governments from developing longer-term outlooks. Perverse incentives for carbon-intensive growth, such as fossil-fuel subsidies, prevent green technologies from gaining competitive advantage. The revolution in shale gas, while environmentally beneficial compared with coal, places downward pressure on carbon-intensive energy sources. This has the effect of making renewables comparatively more costly and less attractive investments. Furthermore, green technologies often cost more at the outset or are more risky investments than conventional alternatives, and this has limited the scope for their expansion into areas where they are needed most. Policy incentives provided by governments for cleanenergy development have in some instances been removed, which has resulted in new policy risks for green-technology investment.

Rising costs from climate change are affecting economic forecasts. Recent storms demonstrate that conventional, business-as-usual investment trends may reduce economic resilience in the future by locking in a carbon-intensive path that leads to costly environmental damage and adaptation costs in the long term ${ }^{16}$. Greening global growth requires a combination of strategically allocating limited public resources, public support to promote private-sector engagement, and increasing investor confidence. It also necessitates a change in future investment priorities and policies, as well as decarbonizing existing and planned infrastructure through carbon capture and storage (CCS) and energy efficiency. Current country emission reduction targets and climate finance pledges fall well short of the required level of action to secure green growth and limit temperature rise to manageable levels ${ }^{17}$.

Government leaders recognize these challenges and have incorporated green growth as an important theme for the G20 and other international processes. At the 2012 G20 Summit in Mexico, the Leaders' Declaration referenced a number of green growth recommendations and welcomed the creation of the Green Growth Action Alliance to advance the green investment agenda (see Box 1). 
Box 1: B20 Task Force on Green Growth: Recommendations from the 2012 B20 Summit in Los Cabos, Mexico

The B20 Task Force on Green Growth proposed five priority actions:

1. Promote free trade in green goods and services: Initiate trade liberalization on sustainable energy products and services to eliminate tariffs, local-content requirements and other non-tariff barriers, and to coordinate industrial and technical standards. Such arrangements will create a tangible, positive incentive within the international trading system to develop and expand the use of green-energy goods and services, helping to accelerate progress on mitigating greenhouse gas emissions while promoting economic growth, access to energy and energy security.

2. Achieve robust pricing of carbon: Ensure a carbon price that is high and sufficiently stable to change behaviours and investment decisions. This will strengthen incentives to invest in economically and environmentally sustainable technologies. G20 leaders should ensure that national targets and policies are ambitious enough to create consistent international demand for carbon units and provide an essential foundation for an international carbon market.

3. End and redirect inefficient fossil-fuel subsidies: Develop national transition plans to phase out inefficient fossil fuel subsidies within the next four years and consider redirecting a portion of such subsidies to ensure access to energy for the poorest and to other public priorities, including green infrastructure investments. This will reduce fiscal imbalances, increase real incomes and reduce greenhouse gas emissions and the overall cost of mitigating climate change.

4. Accelerate low-carbon innovation: Use revenues from carbon pricing measures to increase support for research, development, demonstration and pre-commercial deployment of low-carbon technologies by pooling international efforts. This will underpin innovative resourceand energy-efficient solutions, increase competitiveness and create business opportunities to drive long-term economic growth.

5. Increase the leverage of private investments: Scale up risk mitigation and co-investment funding structures to help close the infrastructure financing gap. G20 leaders should call on sources of public finance to move from a project-by-project approach to a portfolio one to ensure there is support for initial project and programme development.

\section{Aims of this report}

This report is a first step by the Green Growth Action Alliance to deliver on the G20 Leaders' request. It aims to provide a common point of reference to guide policy-makers, financial institutions and investors as they seek to better understand, and address, the global gap in green investment. This report documents and synthesizes the best available green investment data, research and case studies from a number of leading organizations, including Bloomberg New Energy Finance, the Climate Policy Initiative, the International Energy Agency, the Organization of Economic Cooperation and Development, the United Nations Environment Programme, the World Bank Group and the World Resources Institute, and provides important messages for different groups of stakeholders. New analysis is also presented on clean-energy asset finance flows, the findings of which can be used to guide investment decisions and priorities in other sectors.

Policy-makers and development financial institutions can use this report to:

- Develop a common view on global flows of green investment in key sectors

- Analyse the gap between business-as-usual investment levels and the amounts needed to address climate change and other environmental challenges

- Identify successful, replicable interventions that unlock private finance with targeted public policies and public finance

Investors can use this report to:

- Identify the leading green investment sectors and regions

- Demonstrate success in obtaining attractive returns from green investment

- Suggest mechanisms that target public finance and maximize private investment

\section{Report structure}

\begin{tabular}{|c|c|c|}
\hline $\begin{array}{l}\text { Part 1: Green } \\
\text { Investment: } \\
\text { Current Flows and } \\
\text { Future Needs }\end{array}$ & $\begin{array}{l}\text { Part 2: Unlocking } \\
\text { Private Finance }\end{array}$ & $\begin{array}{l}\text { Part 3: Catalysing } \\
\text { Leadership and } \\
\text { Private Investment }\end{array}$ \\
\hline $\begin{array}{l}\text { What are global green } \\
\text { investment flows? }\end{array}$ & \multirow{2}{*}{$\begin{array}{l}\text { What is the role of } \\
\text { public funds and } \\
\text { public policy to } \\
\text { mobilize private } \\
\text { finance for green } \\
\text { growth? }\end{array}$} & \multirow{2}{*}{$\begin{array}{l}\text { What actions are } \\
\text { needed to effectively } \\
\text { scale up green } \\
\text { investment? }\end{array}$} \\
\hline $\begin{array}{l}\text { What investment is } \\
\text { required to achieve } \\
\text { climate change and } \\
\text { sustainability targets? }\end{array}$ & & \\
\hline
\end{tabular}




\section{Part 1: Green Investment: Current Flows and}

Future Needs

\section{Securing green growth}

- Investment required for the water, agriculture, telecoms, power, transport, buildings, industrial and forestry sectors under current OECD growth projections is approximately US\$ 5 trillion per year until 2020.

- However, this business-as-usual investment will not lead to a stable future unless it achieves environmental and sustainability goals. Beyond the known infrastructure investment barriers and constraints, the challenge will be to enable an unprecedented shift in long-term investment from conventionala to green alternatives to avoid 'lock-in'. This can be achieved by re-evaluating investment priorities, shifting incentives, building capacity, investment-grade policies ${ }^{b}$ and improving governance.

- There are additional investment needs of at least US\$ 0.7 trillion per year to meet the climate challenge. This is needed for clean-energy infrastructure, sustainable and low-carbon transport, energy efficiency in buildings and industry, and for forestry, to limit the global average temperature increase to $2^{\circ} \mathrm{C}$ above pre-industrial levels. In other sectors, incremental investment needs are unknown and more work is needed to understand these.

- Estimated separately, the additional investment requirements beyond current spending for adapting to climate change are estimated at US\$0.1 trillion per year in a $2^{\circ} \mathrm{C}$ scenario.

\section{Current green investment flows}

- Green investment flows have been summarized from different sources for climate-specific investment, notably renewable energy, energy efficiency, transport vehicles, forestry and climate change adaptation. In other sectors, such as transport infrastructure (roads and airports), buildings, industry, water and agriculture, flow estimates are lacking but business-asusual spending predictions can be used as a proxy.

- Total investment in climate-change mitigation and adaptation in 2011 were estimated at US $\$ 268$ billion from the private sector and US\$ 96 billion from the public sector (US\$ 364 in total, of which US\$ 14 billion was for adaptation).

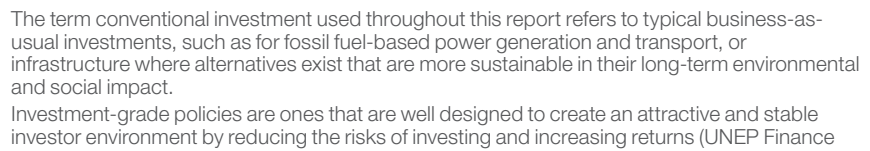
usual investments, such as for fossil fuel-based power generation and transport, or infrastructure where alternatives exist that are more sustainable in their long-term environmental and social impact.

Investment-grade policies are ones that are well designed to create an attractive and stable investor environment by reducing the risks of investing and increasing returns (UNEP Finance Initiative).
- For a subset of this climate-specific investment, namely cleanenergy asset finance, investment has been growing at a rate of $32 \%$ per year since 2004. Investment flows in 2011 were up $93 \%$ from 2007, the year before the global financial crisis. In 2012, Southern-originating flows for clean-energy asset financing are set to exceed those originating from the Northc. Most of this Southern finance is being used domestically and is an important emerging source of capital.

- Looking through the lens of climate-specific investment, financial flows still fail to close the cost gap. There is significant regional and technological bias in investment patterns. Investment is disproportionately focussed in the North and emerging markets, for wind and solar technologies in particular. To support global green growth and meet emission-reduction goals in a $2^{\circ} \mathrm{C}$ scenario, investment needs to rapidly scale up in other non-OECD countries and in general for renewable technologies beyond wind and solar. Investment in energy efficiency and sustainable transport are also lagging.

- Financing for climate-specific investment was split about 1:3 between public- and private-sector investments in 2011. Part 2 of this report elaborates on the strong potential for increased private sector participation.

\section{Box 1.1: Defining the scope and methodology}

\section{Scope of the report}

In order to measure, monitor and scale up progress in green investment, it is first necessary to define its scope. Efforts to date have focused on measuring and tracking investments to reduce greenhouse gas emissions (mitigation) and to reduce the risks and impacts of climate change (adaptation). Global spending on infrastructure has generally been tracked separately. The diagram below presents a conceptual framework for greening investment with the scope of assessment for this edition of this report. There is no comprehensive assessment of investment in the various sectors. Data gaps have been identified for current investment flows and future investment requirements in nonenergy related sectors. Future editions of this report will aim to offer strategies to close these gaps, with a longer-term aim of obtaining a clearer picture of green-growth spending. 
Figure 1.1: Conceptual assessment framework and scope of this report

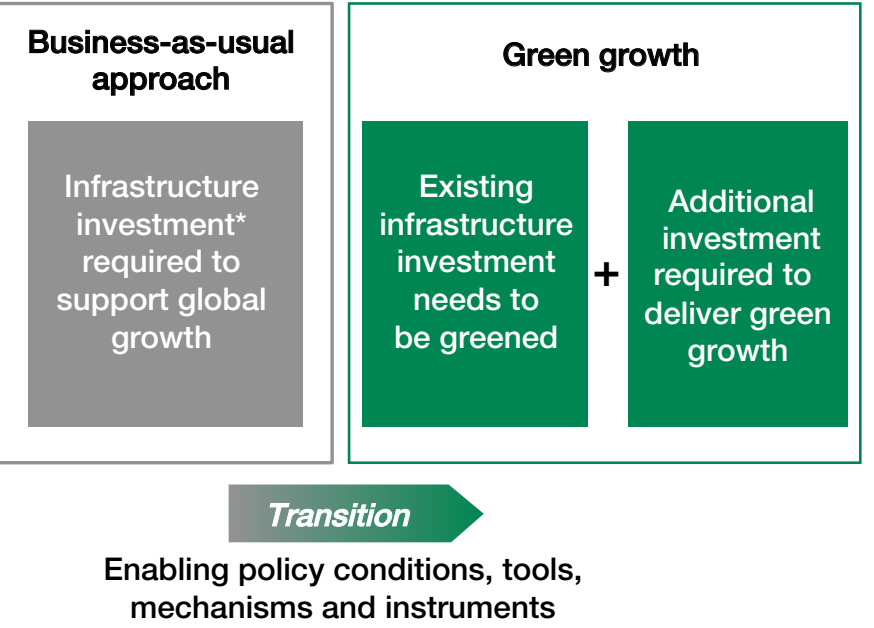

Notes: *Sectors assessed include water, agriculture, forestry, telecommunications, transport, power, buildings and industry. ^Quantity of business-as-usual investment that needs to be 'greened' is no assessed. \#Sectors assessed limited to transport vehicles, power, industry, buildings and forestry.

The frame of the assessment, which can be expanded in later editions, includes a synthesis of investment requirements from different sources (detailed in Appendix 1) to support growth under current projections. A subset of this business-as-usual investment needs to be 'greened' to ensure that investments are sustainable for a transition to green growth. This subset, however, has not been quantified in this edition of the report.

In addition to investment for growth, additional investment is needed beyond business-as-usual spending in order for green technologies to limit climate-change temperature increases to $2^{\circ} \mathrm{C}$ above pre-industrial levels. This is assessed for transport vehicles, power, industry, buildings and forestry, but is unknown for other sectors, such as agriculture and water. The combination of 'greened' business-as-usual investment and investment needed for green technologies comprise the total investment needs in a green-growth model for securing a sustainable future under a $2^{\circ} \mathrm{C}$ scenario.

The assessment of sectors in this edition of the report is not exhaustive and is based on data availability. Future editions will aim to expand the number of sectors assessed and the scope of that assessment.

\section{Defining green growth and green investment}

Various definitions of green growth exist ${ }^{18}$. For the purposes of this report the definition adopted by the Secretary-General of the United Nations (UNSG) High Level Panel on Global Sustainability is applied. The High Level Panel sets out a vision for growth that eradicates poverty and reduces inequality, while combating climate change and respecting a range of other planetary boundaries. In this context, an inclusive green-growth strategy is an important driver for innovation and creating sustainable wealth ${ }^{19}$.

Green investment is a broad term closely related to other investment approaches such as socially responsible investing (SRI) and sustainable, long-term investing. As most green investment is needed to retrofit existing and develop new infrastructure ${ }^{d}$, this report focuses on infrastructure spending but acknowledges the need for non-infrastructure spending, such as for capacity building, deployment, training and research and development, to enable green and inclusive growth ${ }^{20}$.

Infrastructure can be defined as the basic physical and organizational structures and facilities needed to operate a society or enterprise that enables economic growth and facilitates the everyday life of citizens. Infrastructure can refer to transport (vehicles, roads, rail), water, energy and telecommunications. Green infrastructure can be defined as infrastructure that enables economic growth and at the same time improves the environment (quality of air, health of citizens), helps conserve natural resources, reduces emissions and enables adaptation to climate change. low-carbon vehicles and transport, and energy-efficient, climate-resilient buildings.
Methodology

This report collects and analyses three categories of data:

Investment requirements in a business-as-usual scenario, under current policies. These are estimates of investment requirements to 2030 to support economic growth projections in a range of sectors, based on models and predictions from the OECD, the World Bank, the Food and Agriculture Organization (FAO) and United Nations Environment Programme (UNEP), in a scenario where green growth and climate change is not a priority.

Investment requirements in a $2^{\circ} \mathrm{C}$ scenario, where climate change is a priority. These are estimates from the International Energy Agency (IEA), UNEP and the World Bank of investment requirements to 2030 in a range of sectors based on a scenario where the effects of climate change are kept at bay.

Current known and historical investment flows. These are limited to climate-specific investments: mitigation and adaptation, summarized by the Climate Policy Initiative ${ }^{e}$.

The investment landscape and cost gap: Business-as-usual investment data was collated from the sectors outlined above and is presented below. Any incremental costs were calculated by subtracting the investment requirements in a scenario that aims to stabilize the global climate at $2^{\circ} \mathrm{C}$ from those under a business-asusual scenario. Climate-change adaptation investment requirements were not aggregated and are presented separately. Collated data was not altered in any way, apart from converting United States dollar amounts to their 2010 rate for ease of comparison. All data sources, assumptions and calculations are provided in Appendix 1. It should be noted that the investment gaps presented in this report should be taken as indicative, and as a lower-range estimate, because further work is required to include other sectors and incremental costs to strengthen the scope of the analysis.

Green investment flows: A subset of climate-specific public and private investment is studied in more depth. Of this investment, new-build asset finance for clean energy (comprising about half of the total investment) is presented in directional flows between countries and domestic sources of finance.

About US\$ 5 trillion in global infrastructure investment is required per year to 2030 in various sectors; this investment must be greened to secure future growth

To support a future global population of 9 billion people an estimated US\$ 5 trillion per year needs to be invested in global infrastructure ( US\$ 100 trillion over the next two decades, Figure 1.2). This business-as-usual approach would maintain investment in conventional, emissions-intensive technologies, endangering future growth. A 2012 World Bank report ${ }^{21}$ highlighted that the planet is on track for a global average temperature rise of at least $4^{\circ} \mathrm{C}$ beyond pre-industrial levels, which would bring impacts detrimental to growth, including unprecedented heat waves, severe droughts and major floods. The McKinsey Global Growth Institute has estimated that rates of environmental degradation are unsustainable for the long-term functioning of the global economy ${ }^{22}$. Existing and future investment, therefore, must be greened to avoid dangerous levels of climate change and adverse environmental impacts that could erode the benefits from new green developments; if non-green investments continue to grow in parallel with increased investment in green infrastructure, it will not be possible to achieve green growth ${ }^{f}$.

The scope of current mitigation flows includes: investment in renewable energy generation, energy efficiency, sustainable transport, agriculture, forestry and land-use, waste and waste water, capacity building and technical assistance, fuel switching and others. The scope of current adaptation flows includes: investment in agriculture and forestry, water preservation, supply and sanitation, infrastructure, capacity bullding and technical assistance, disaster risk reduction and others.

For example, the World Resources Institute estimate that 1,199 new coal-fired power plants with a combined capacity of 1.4 TW are currently being proposed globally, with China and India together accounting for $76 \%$ of the proposed capacity (Global Coal Risk Assessment, WRI, November 2012). Without carbon capture and storage, these investments significantly dampen the benefits of parallel investment in clean energy. 
Figure 1.2: Total estimated business-as-usual investment requirements and additional investment under a $2^{\circ} \mathrm{C}$ scenario

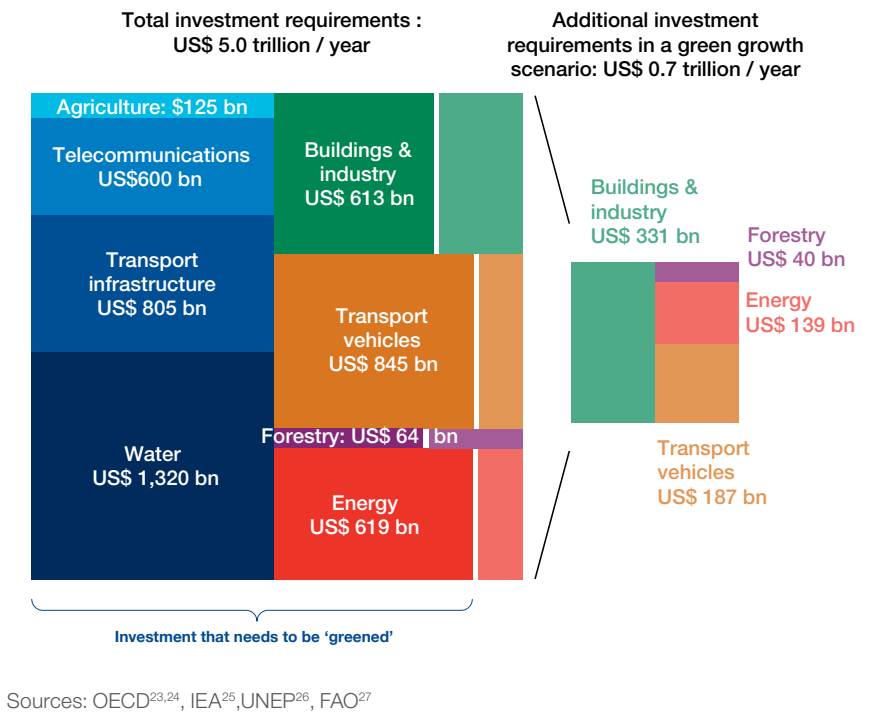

While greening investment is one aspect of the challenge, the key is to secure financing for infrastructure needs in general. Approximately US\$24 trillion is earmarked to be spent on infrastructure before 2030, falling short of the cumulative US\$ 60 trillion needed ${ }^{28}$. Development capital needs are in addition to the annual US\$ 5 trillion figure cited in this report, and the IEA estimates that the share of energy-related investment in public research, development and demonstration has fallen by two thirds since the $1980 s^{29}$. Better inter-agency planning and strategic integration is required to determine common greengrowth goals between sectors.

More work is needed to better understand the investment needs in the agriculture, water, transport infrastructure and telecommunications sectors. In the power generation, buildings, industry and transport vehicles sectors, the IEA has estimated there will be significant incremental capital costs for technologies beyond business-as-usual spending. Business-as-usual and incremental costs in sectors beyond the scope of assessment have not been assessed in this edition of the report.

It is possible that for some sectors, the incremental costs could be lower for some types of infrastructure in a $2^{\circ} \mathrm{C}$ scenario compared with a business-as-usual scenario. For example, investment in infrastructure to transport and distribute oil and gas should be less than the US\$ 155 billion per year (2005 US\$) projected by the OECD under a business-as-usual approach. Transporting fossil fuels accounts for more than $40 \%$ of the tonnage of maritime trade and more than $40 \%$ of rail tonnage in the USA; so the expected increases in investments in port and marine infrastructure under a business-as-usual approach should be lower in a $2^{\circ} \mathrm{C}$ scenario ${ }^{30}$.

In all sectors, the green-growth challenge is multi-faceted:

- Capital costs for infrastructure to support growth are high and not being met. Other than clean energy, investment flows are not well documented.

- To ensure growth is sustainable, an unprecedented shift in long-term investment is required from conventional to green alternatives, producing synergies between development and the greening of growth.

- There are also incremental investment needs for technologies such as CCS that carry greater risks for investors.

- Research and development spending is equally important to help demonstrate and commercialize green technologies.
Table 1.1 collates and normalizes as much as possible the investment requirements from different sources for various sectors under business-as-usual growth and under a $2^{\circ} \mathrm{C}$ scenario.

The next section in this chapter focuses on the agriculture and water sectors, where the incremental costs under a $2^{\circ} \mathrm{C}$ scenario are not well known; a qualitative explanation is offered. More work is also needed to understand the financial implications for adaptation in the IEA's Current Policies $\left(6^{\circ} \mathrm{C}\right)$ scenario, and the incremental costs for the telecommunications sector. Finally, this chapter estimates incremental costs (under a $2^{\circ} \mathrm{C}$ scenario) for the energy, buildings, industry, transport and forestry sectors.

Table 1.1: Annual estimated investments needed under a business-as-usual and low-carbon scenario (US\$ billions per year between 2010 and 2030)

\begin{tabular}{|c|c|c|c|c|c|c|c|}
\hline \multirow[b]{2}{*}{ 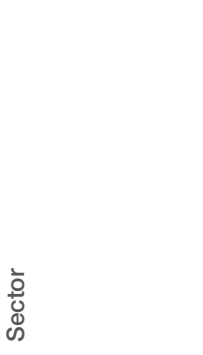 } & \multicolumn{2}{|c|}{$\begin{array}{l}\text { Business-as- } \\
\text { usual scenario } \\
\text { investment } \\
\text { needs }\end{array}$} & \multicolumn{2}{|c|}{$\begin{array}{l}2^{\circ} \mathrm{C} \text { scenario } \\
\text { investment } \\
\text { needs }\end{array}$} & \multicolumn{2}{|c|}{$\begin{array}{l}\text { Incremental } \\
\text { investment } \\
\text { required }\end{array}$} & \multirow[b]{2}{*}{ 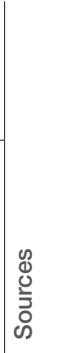 } \\
\hline & 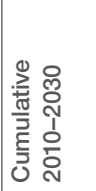 & 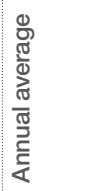 & 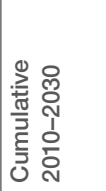 & 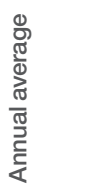 & 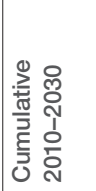 & 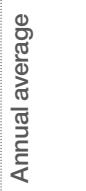 & \\
\hline Power generation & 6,933 & 347 & 10,136 & 507 & 3,203 & 160 & IEA \\
\hline $\begin{array}{l}\text { Power } \\
\text { transmission and } \\
\text { development }\end{array}$ & 5,450 & 272 & 5,021 & 251 & -429 & -21 & IEA \\
\hline Energy total & 12,383 & 619 & 15,157 & 758 & 2,774 & 139 & \\
\hline Buildings & 7,162 & 358 & 13,076 & 654 & 5,914 & 296 & IEA \\
\hline Industry & 5,100 & 255 & 5,800 & 290 & 700 & 35 & IEA \\
\hline $\begin{array}{l}\text { Building \& } \\
\text { Industrial total }\end{array}$ & 12,262 & 613 & 18,876 & 944 & 6,614 & 331 & \\
\hline Road & 8,000 & 400 & $8,000 ?$ & $400 ?$ & - & - & OECD \\
\hline Rail & 5,000 & 250 & $5,000 ?$ & $250 ?$ & - & - & OECD \\
\hline Airports & 2,300 & 115 & $2,300 ?$ & $115 ?$ & - & - & OECD \\
\hline Ports & 800 & 40 & $800 ?$ & $40 ?$ & - & - & OECD \\
\hline Transport vehicles & 16,908 & 845 & 20,640 & 1,032 & 3,732 & 187 & IEA \\
\hline Transport total & 33,008 & 1,650 & 36,740 & 1,837 & 3,732 & 187 & \\
\hline Water & 26,400 & 1,320 & $26,400 ?$ & $1,320 ?$ & - & - & OECD \\
\hline Agriculture & 2,500 & 125 & $2,500 ?$ & $125 ?$ & - & - & FAO \\
\hline Telecommunications & 12,000 & 600 & $12,000 ?$ & $600 ?$ & - & - & OECD \\
\hline Forestry & 1,280 & 64 & 2,080 & 104 & 800 & 40 & UNEP \\
\hline Other sectors & unknown & inknown & unknown & unknown & unknown & unknown & \\
\hline \multirow[t]{2}{*}{ Total investment } & 99,833 & 4,991 & 113,753 & 5,689 & 13,934 & 698 & \\
\hline & $\sim 100$ tr & $\sim \$ 5 \mathrm{tr}$ & $\sim \$ 114 \mathrm{tr}$ & $\sim 5.7 \mathrm{tr}$ & $\sim \$ 14$ tr & $\sim 0.7$ tr & \\
\hline
\end{tabular}

Sources: OECD ${ }^{31}, 32, \mathrm{IEA}^{33}, \mathrm{FAO}^{34}, \mathrm{UNEP}^{35}$. Data presented in US $\$ 2010$ rates.

Note: Total investment does not include synergy effects that can occur between other investments besides energy, buildings and industry and transport. The total amount provided is a proxy of future investment. Investment in water and telecommunications infrastructure covers the OECD and emerging markets only. Investment in agriculture covers 93 developing countries only. See Appendix 1 for full details of assumptions, scope and calculations. 


\section{Agriculture}

The Food and Agriculture Organization (FAO) has estimated the gross investment requirements for primary agriculture in developing countries at US\$125 billion per year to 2030. The FAO further breaks this investment down by the need to replace existing capital stock (60\%) and for new capital stock (40\%) to increase agricultural productivity to double current levels by $2050^{36}$. In practice this means that energy for production will need to be low carbon (for both vehicles and electricity needs), and research and development will need to focus on livestock and crop practices that reduce emissions, require less fertilizer and chemical input, and provide climate-resilient crop varieties. Agricultural growth needs to be more inclusive, supporting the equitable reduction of poverty and hunger, and balanced with preserving existing high-value ecosystems. This productivity revolution in the sector could require additional costs beyond current spending but no estimates exist of the incremental cost for greening the agricultural sector.

The International Food Policy Research Institute estimates that only $6 \%$ of investment in agriculture in developing countries is from private sources, compared with $55 \%$ in developed nations ${ }^{37}$. Private investment from foreign and domestic sources will need to be mobilized to deliver most capital requirements, particularly for equipment, to develop infrastructure and maintenance, and for research and development for new crop varieties and breeds. Reducing subsidies for input-intensive agriculture could release funding to bring about private investment.

\section{Water}

As the world's population tripled in the 20th century, water consumption increased in absolute amounts and per capita. Rapid demographic and economic growth has put increasing pressure on the quality and quantity of water resources. With a growing population, water resources must be managed effectively to address water pollution, excessive consumption, preserve the ecology and the environment, and to safeguard the hydrological cycle in general while providing adequate, longterm supplies of acceptable-quality water for domestic, industrial and agricultural needs.

The OECD estimates that US\$1.3 trillion' ${ }^{g}$ needs to be invested annually ${ }^{38}$ to replace and maintain water infrastructure in developed countries and emerging markets alone. In addition to these baseline financial needs, effective policies and finance are needed to support new, resilient infrastructure.

\section{Climate change adaptation}

A world that is at least $2^{\circ} \mathrm{C}$ warmer than in pre-industrial times will experience heightened rainfall and more frequent and intense weather events, such as flooding, droughts and heat waves. The Intergovernmental Panel on Climate Change's (IPCC) Fourth Assessment Report illustrates the strong links between climate adaptation and growth. For example, more than one sixth of the world's population lives in areas supplied by glacial melt water, and as glaciers decline, so will long-term water availability. Coastal areas are in danger of being flooded due to impending rises in sea levels, with poorer communities the most vulnerable due to lack of adaptive capabilities. Highly negative health impacts are predicted from increased transmission of disease ${ }^{39}$.
The World Bank estimates the cost of adapting to a $2^{\circ} \mathrm{C}$ increase in global average temperatures will be US\$ 85-121 billion ${ }^{\mathrm{h}}$ per year between now and $2050^{40}$. However, under the IEA's Current Policies scenario $\left(6^{\circ} \mathrm{C}\right)$, adaptation costs will be significantly higher and have not yet been fully estimated, for example, to ensure that disasters are managed and development is more resilient to extreme weather events. Furthermore, there is no certainty that adaptation is possible beyond $2^{\circ} \mathrm{C}$ of warming ${ }^{41}$. The Climate Policy Initiative estimates investment flows for climate adaptation of US\$ $12-16$ billion in $2011^{42}$, implying a shortfall of US\$ 69-109 billion per year in adaptation investment.

At least US\$ 0.7 trillion in incremental costs beyond businessas-usual spending is required to support green growth

Aside from the challenge of greening investment in the sectors described above, to achieve climate stabilization at $2^{\circ} \mathrm{C}$ at least US\$0.7 trillion in incremental, net investment is needed beyond spending under a business-as-usual approach (a further US\$ 14 trillion by 2030). Data on current and historical investment flows in low-carbon transport, building energy efficiency and green industrial spending is insufficient. Further analysis is needed to improve estimates of the necessary investment flows beyond what is predicted under a business-as-usual scenario. To define the incremental cost gap, this section assumes investment will follow a business-as-usual path in line with the IEA's Current Policies $\left(6^{\circ} \mathrm{C}\right)$ scenario.

The incremental costs are for investments in power generation, transport vehicles, energy efficiency in buildings and industry (sourced from the IEA) and forestry (sourced from UNEP Finance Initiative). The US\$ 0.7 trillion per year in net new investment takes into account an estimated US\$ 146 billion per year in business-asusual energy spending that would need to be redirected from conventional outlays for fossil fuel-powered electricity, heat and transport to less-emitting options. Setting forestry aside, half of the incremental cost is needed for energy efficiency while the remainder is needed to cover investments to decarbonize power generation and transport.

The IEA estimates that these incremental costs are economically viable: the corresponding predicted fuel savings will more than compensate for the higher investment needs in the transition to a low-carbon energy sector. Between 2010 and 2050 , even when applying a $10 \%$ discount rate to savings from reduced demand for coal, gas and oil, the IEA forecasts a net saving of about US\$ 5 trillion over the period, indicating that decarbonizing the energy system is clearly affordable ${ }^{43}$.

More spending will need to be diverted from conventional to clean power in the future, with a much higher proportion of spending targeted in the renewables sector under a $2^{\circ} \mathrm{C}$ scenario

The IEA estimates that total investment requirements of the power sector are US\$ 758 billion per year or US\$15 trillion to 2020j (Figure 1.3).

Investments are needed in conventional (fossil) and clean and renewable technologies but reduced investment in fossil fuel-based energy generation provides some relief (46\%) towards the incremental capital required for renewables, nuclear and carbon capture and storage.

For coal and gas power, carbon capture and storage is a critical technology that requires much greater investment; US\$ 52 billion per year in total to 2030 on top of the investment needs for gas and coal power generation.

By 2050, almost all gas and coal power infrastructure will need to have carbon capture and storage under the $2^{\circ} \mathrm{C}$ scenario ${ }^{44}$.

Numbers adjusted to US $\$ 2010$ rates.

See Appendix 1 for a breakdown of investment needs and sectoral scope assumptions. Power sector investment scope includes: coal, gas, transmission and distribution, renewable energy such as wind, solar and others, nuclear and carbon capture and storage. 
Figure 1.3: Total estimated investment required per year to 2030 in power generation (US\$ billions)

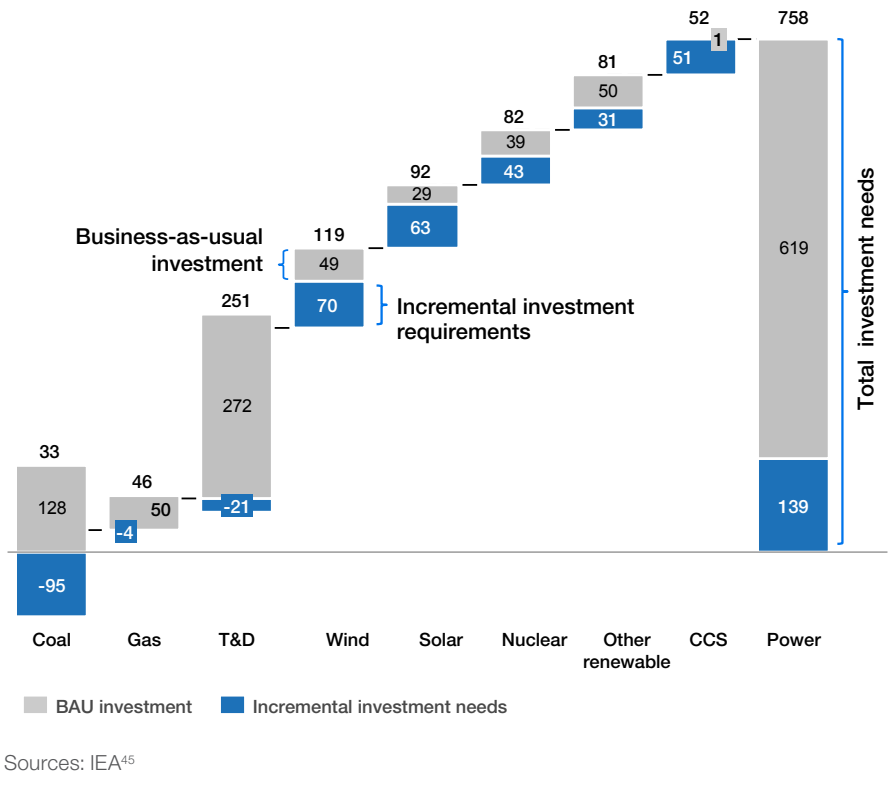

Fuel savings from gasoline and diesel more than compensate for the incremental costs required in the transport sector

- The IEA estimates that more than US\$1 trillion per year to 2030 is needed in transport vehicle investment ( US\$ 21 trillion over the next two decades) ${ }^{46}$; the OECD predicts that a further US\$ 0.8 trillion is needed per year in transport infrastructure.

- The net additional investment required compared with a business-as-usual scenario is estimated at US\$187 billion per year, taking into account a diversion of US\$26 billion per year from gasoline vehicles to greener alternatives, such as hybrid vehicles, electric and natural-gas powered vehicles.

- Under the $2^{\circ} \mathrm{C}$ scenario, US\$ 784 billion per year will become available from gasoline and diesel-fuel savings, of which just US\$ 69 billion will be needed to cover increased costs of natural-gas usage, biofuels, electricity and hydrogen.

Approximately US\$296 billion per year in incremental energyefficiency investment is needed in the buildings sector to 2030

- The IEA estimates that more than US\$13 trillion overall needs to be invested in energy efficiency over the next two decades in the buildings sector. This will be crucial to reduce the demand for producing new energy.

- New buildings will need to meet stringent energyperformance requirements, while existing buildings will need retrofits with longer paybacks; this raises the importance of financing mechanisms, discussed further in Part 2 of this report, to help unlock energy efficiency investment for commercial and residential buildings.

Incremental costs in the industrial sector are estimated at US\$ 35 billion per year to 2030

- In the five most energy-intensive sectors (cement, iron and steel, pulp and paper, aluminium and chemicals and petrochemicals), significant opportunities exist in improved energy management, fuel switching, recycling and carbon capture and storage to capture process emissions.

- Compared with a business-as-usual scenario, the incremental investment required for a $2^{\circ} \mathrm{C}$ pathway is lower than in other sectors, estimated by the IEA at US\$ 35 billion per year ${ }^{47}$.
An additional US\$ 40 billion per year is needed in the forestry sector

Forests play a central role in climate regulation and carbon sequestration, and one billion people rely on forest ecosystems for shelter, food, fuel, jobs, water, medicine and security. The Food and Agriculture Organization has estimated that the forest industry contributed almost US\$ 0.5 trillion to global GDP in $2006^{48}$. Competition from other industries, such as agriculture, for land use puts pressure on forest ecosystems, resulting in the current unsustainable rates of deforestation. In many countries, much of the native forest cover has been stripped to support charcoal production, and in others, reliance on wood fuel for cooking can lead to increased pressures on local forests and natural resources ${ }^{49}$.The green investment challenge for forests is to provide policies and incentives that help avoid unsustainable deforestation, encouraging green growth and driving resource productivity, particularly in developing countries.

- UNEP estimates that approximately US\$ 64 billion is invested in forests annually ${ }^{\mathrm{m}}$, of which $28 \%$ is spent on forest management and the remainder invested in forest product processing and trade.

\section{- An additional investment of US\$ 40 billion per year is} needed for reforestation ( $54 \%$ of the total) and to pay landholders to conserve their forests (46\% of the total).

- Through this additional investment, forest area is predicted to increase, leading to $28 \%$ higher carbon storage, greater employment and a gross added value of US\$ 600 billion in 2050 compared with a business-as-usual scenario.

Climate-specific investment flows are growing, with US\$268 billion invested per year from the private sector and US\$96 billion per year from the public sector

While data from IEA and UNEP indicate at least US\$ 0.7 trillion in incremental costs for the sectors outlined above, the Climate Policy Initiative estimated that approximately US\$ 364 billion was invested globally in climate-specific project investment in 2011. Of this, US\$ 14 billion was for adaptation ${ }^{n}$ and the remainder for mitigation, chiefly for renewable energy generation (54\% of mitigation investment), energy efficiency (18\%), sustainable transport (10\%) and other projects ${ }^{\circ}$, including land use, waste and fuel switching ${ }^{50}$. The ratio of public to private investment was about 1:3 in 2011 (see Figure 1.3). Private sources of investment dominated, with approximately one-third of overall climatespecific investment originating from project developers.
Calculations as of 2006

Climate-specific investment flows for adaptation are estimated by the Climate Policy Initiative (2012) from various sources and include: agriculture and forestry; water preservation; supply and sanitation; infrastructure; capacity building/technical assistance; disaster risk reduction, and others.

Other climate-specific investment flows for mitigation include agriculture, forestry, land-use, waste and waste water, capacity building/technical assistance, fuel switching and others. 
Figure 1.4: Climate change mitigation and adaptation investment by source of finance (US\$ billions)

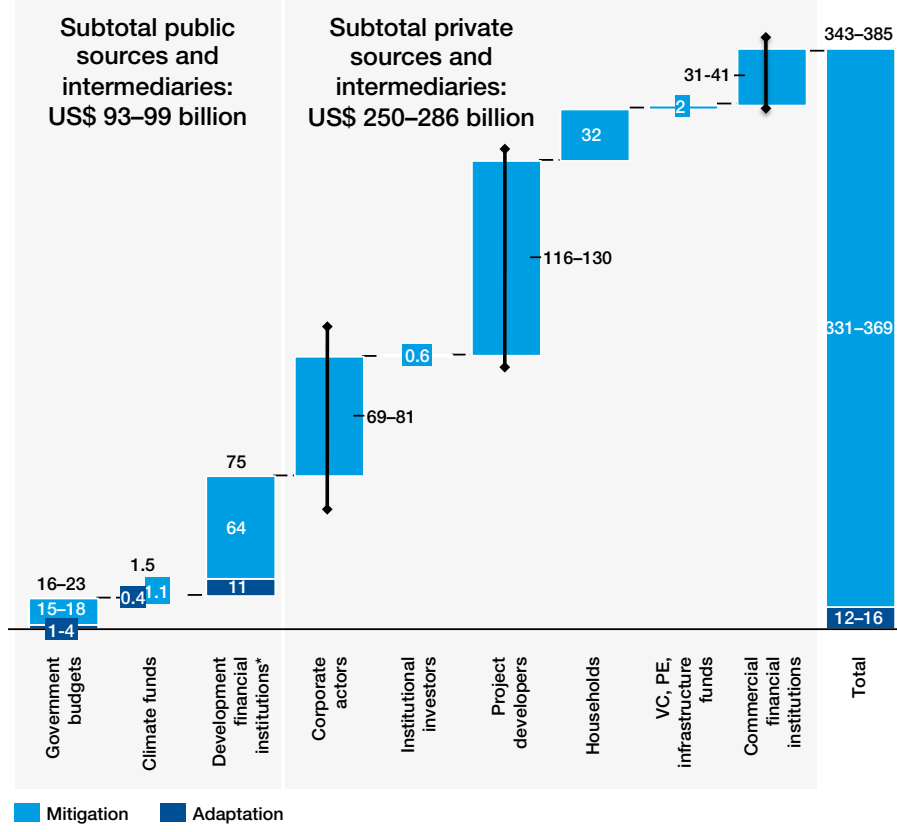

* Development financial institutions include national, bilateral and multilateral financial institutions. $\mathrm{VC}=$ venture capital; $\mathrm{PE}=$ private equity

Source: Climate Policy Initiative ${ }^{51}$

Investment in clean energy has rapidly grown over the past few years

Investment in clean energy ${ }^{p}$ grew at an average rate of 33\% per year between 2004 and 2011, with the highest growth in the solar sector ${ }^{52}$. Rapid growth in the industry has partially resulted from the reduced cost of wind and solar power combined with more generous subsidy programmes. Bloomberg New Energy Finance estimates that small-scale solar projects (less than 1 megawatt) alone attracted US\$22 billion in the second quarter of 2012, 13\% up from the same quarter in the previous year. Over 2011, solar module prices fell by 50\%, and by the end of 2011 it was also clear that installed renewable energy had surpassed overall installed nuclear capacity by $50 \%$ globally ${ }^{53}$.

Clean energy technologies have experienced dramatic cost reductions, due to:

- the adoption by many countries of clean energy policies and frameworks over the past decade

- growth in emerging markets

- beneficial economic stimulus packages favouring clean energy investment

- rising costs of fossil fuels

The past year, however, has brought signs of slowing investment in wind and solar energy as governments have reduced subsidies ${ }^{q}$. Demand has also dropped following a fall in industrial output during the global financial crisis, and the current oversupply in the solar and wind sectors could lead to consolidation in the market in the short to medium term ${ }^{54}$.
In the longer term, the current revolution in shale gas could place downward price pressure on carbon-intensive energy sources, making renewables comparatively less attractive investments. While gas (which is less carbon-intensive than coal) will continue to be part of the energy mix in a green-growth scenario, its contribution will need to decrease over time to less than 3\% of overall power investment needs by 2050, according to the IEA ${ }^{55}$. Avoiding gas 'lock-in' will be a major challenge for governments in the coming decade.

Figure 1.5: Growth in clean energy investment, by technology (US\$ billions)

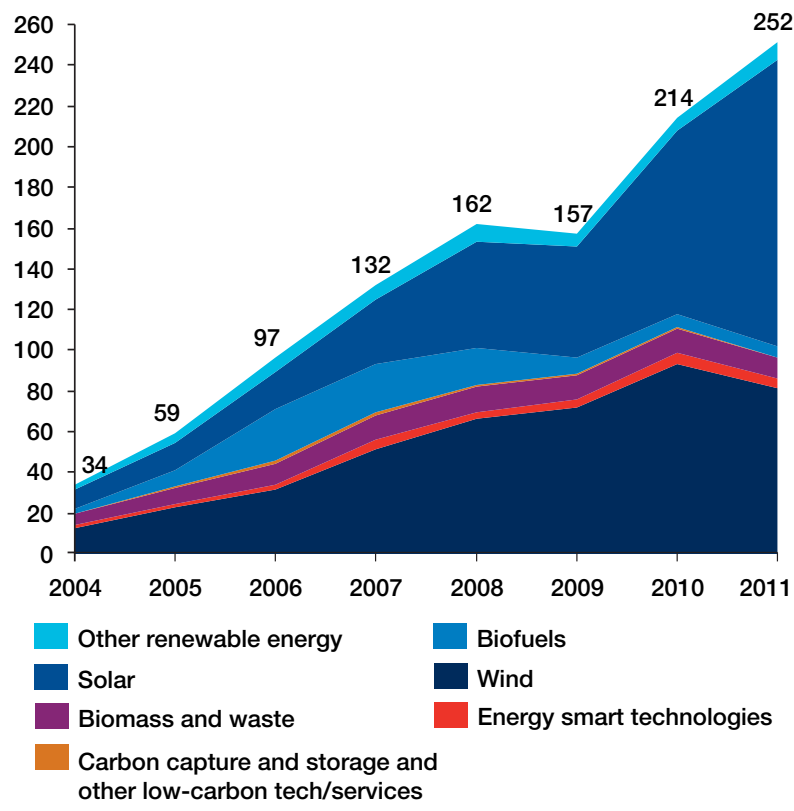

Note: Data includes clean energy asset finance, public markets, small distributed capacity (solar photovoltaic), venture capital and private equity funding and adjustments for reinvested equityr. Source: Bloomberg New Energy Finance ${ }^{56}$

Global green investment could be accelerated by focusing more on developing country markets as a source of investment

Looking through a clean energy lens, investment in asset finance originating from non-OECD countries for both domestic and cross-border uses grew from US\$ 4.5 billion in 2004 (19\% of total asset finance) to US\$ 68 billion in 2011 (41\% of total asset finance), at a rate of $47 \%$ per year (see Figures 1.5, 1.6). Foreign cross-border investment from outside the OECD represented the highest growth rate in any clean energy flow category: 61\% per year on average, a 28-fold increase ${ }^{57}$. Based on current growth rates in investment originating in non-OECD countries, clean-energy asset finance flows are expected to exceed those originating from the OECD in 2012. In the wake of the global financial crisis, investment originating from nonOECD countries did not slow as much as those from the OECD, highlighting their resilience and potential as a source of future investment for green growth.
Clean energy asset finance as reported in the Bloomberg New Energy Finance database. Scope includes the new-build financing of renewable energy-generating projects, which includes both electricity generating and biofuels production assets. Projects may be financed via the balance sheets of the project owners or through financing mechanisms, such as syndicated equity from institutional investors, or project debt from banks.

Germany, the UK and Spain are examples where solar photovoltaic feed-in-tariff rates and subsidies have been reduced, while in the USA, wind installations are falling, due partly to the federal Production Tax Credit expiring. India and China are also phasing out tax incentives for wind energy.
Public markets: Funds raised by publicly quoted or over-the-counter/off-exchange trading (OTC) supported clean energy companies on the capital markets; Venture capital and private equity: Early- and late-stage venture capital funding rounds of clean energy companies as well as funds raised privately for expansion; Small distributed capacity: Estimated data of non-tracked investment in small scale solar photovoltaic $(<1$ megawatt). Data sourced from Bloomberg New Energy Finance, 2012 
Figure 1.6: Current estimated climate-specific investment flows in 2011 (US\$ billions)
OECD

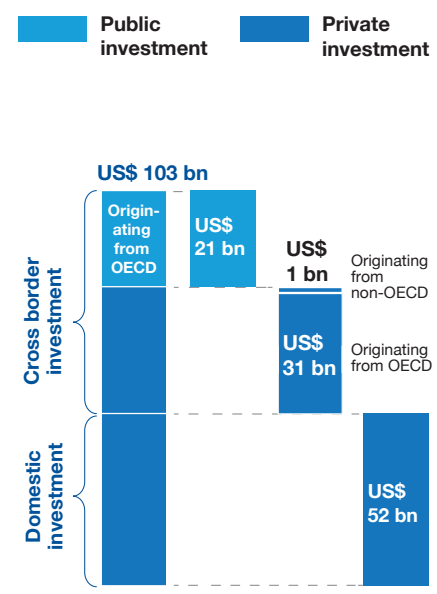

\section{Non-OECD}

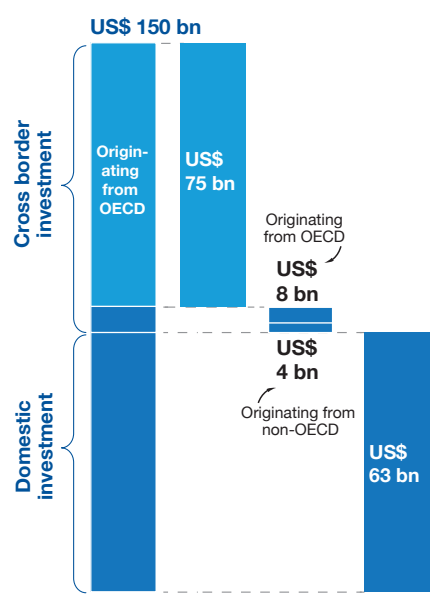

Note: Excludes the following private money flows: small-scale distributed solar photovoltaic investment (US\$ 73 billion), venture capital/private equity/public markets/reinvested equity adjustment (US\$13 billion), and other unknown private flows. Private finance flows include new-build clean-energy asset finance only. Public finance flows estimated by the Climate Policy Initiative (2012) and includes climate-change adaptation flows (total US\$ 14 billion). Sources: Bloomberg New Energy Finance ${ }^{58}$ and the Climate Policy Initiative ${ }^{59}$

Figure 1.7: Historical clean energy investment by flow type (US\$ billion)

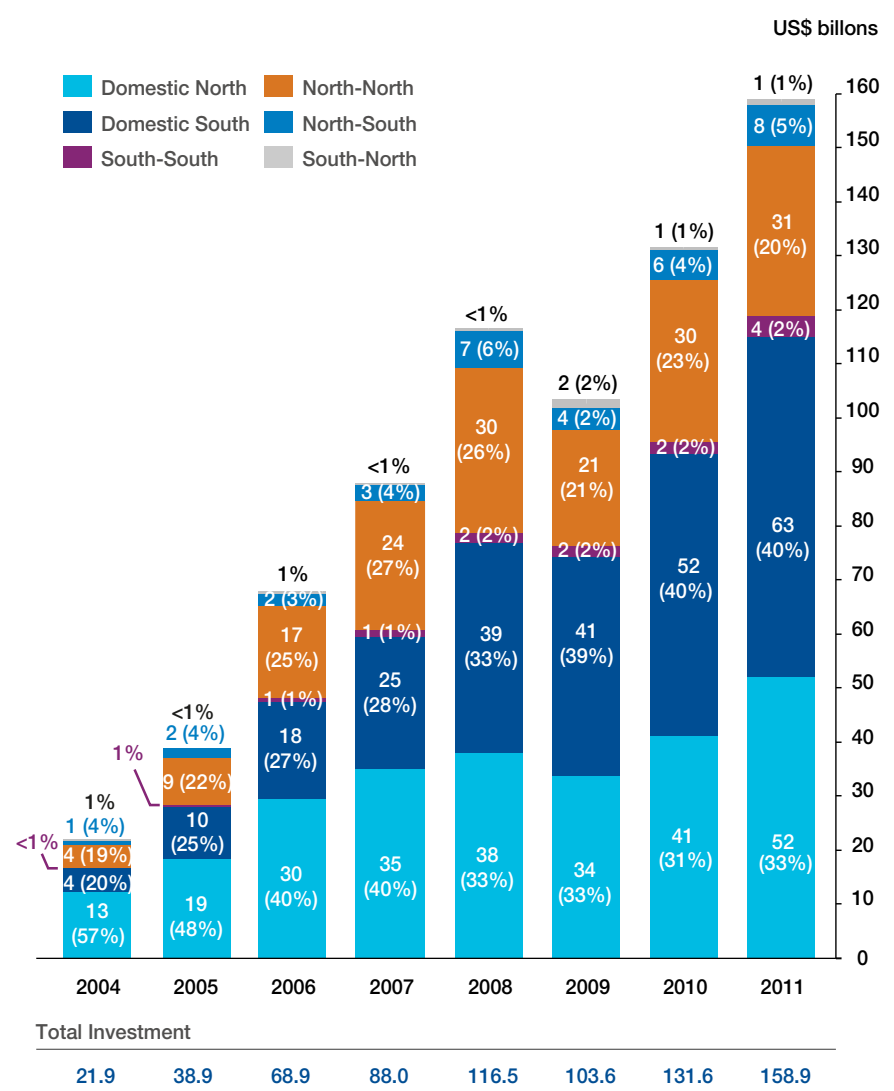

Note: Data includes new clean-energy asset finance only, and excludes unknown flows, public markets, small distributed capacity (solar photovoltaic), venture capital and private equity funding and adjustments for reinvested equity.

Source: Bloomberg New Energy Finance ${ }^{60}$
Targeted public action can address the investment shortfall and promote green investment

The need to scale up green investment is evidenced through the example of clean energy. As outlined above, total investment needs in the power sector in the IEA's $2^{\circ} \mathrm{C}$ scenario are US\$758 billion annually. Out of this total, 39\% (US\$ 294 billion) is required for renewable energy. Climate-change mitigation flows are estimated at US\$350 billion per year by the Climate Policy Initiative (taking into account both public- and private-sector flows), of which an estimated US\$189 billion was spent on renewable energy projects in $2011^{61}$. This indicates a shortfall of about US\$100 billion per year. While this may seem a relatively small amount, in reality the shortfall is larger because investment is biased towards wind and solar technologies in the OECD and emerging markets. Investment in other types of renewableenergy technologies need to be scaled up equitably across regions in order to meet the emission-reduction targets predicted by the IEA. Larger investment gaps in Africa and other non-OECD countries beyond the emerging markets will be challenging to close given the higher level of investment risk in these areas.

The Climate Policy Initiative estimated flows in energy efficiency investment at US\$ 63 billion in 2011, with sustainable transport investment at US\$ 35 billion $^{62}$. While there is a lack of comprehensive data on investment, these early estimates show that these sectors fall short of the required incremental investment (US\$ 331 and US\$ 187 respectively).

Bloomberg New Energy Finance estimates that annual flows in clean energy are increasing more rapidly than in conventional, fossil-fuel energy investment. Despite this, overall annual investment in fossil-fuel energy remains higher than cleanenergy spending ${ }^{63}$. While fossil fuels form part of the required energy mix in the future, investment needs to decrease over time, with a shift to greener technologies.

The public sector can address the green investment gap by unlocking private investment through targeted financial mechanisms that reduce risk and lower the cost of capital. At the same time, greener alternatives need to be promoted over conventional ones through better policy frameworks and a shift in incentives and behaviour. Strong carbon-pricing signals and removing fossil-fuel subsidies, in particular, play an important role in the transition. These actions, if successful, can promote long-term financing for green technologies and alleviate the barriers to investment. Part 2 of this report expands on these barriers and the potential instruments and actions that can help unlock the investment needed to support greener growth. 


\section{Part 2: Unlocking Private}

Finance

Greening growth will require a significant reconfiguration of current and future investment, with further incremental costs beyond a business-as-usual approach that need to be financed. Given the current financial crisis, public resources are limited, however, and the reliance on public-sector investment in the longer term must be reduced to ensure sustainable green growth. This places private finance at the core of the transition.

Unlocking private finance can be challenging: certain green technologies have real or perceived higher risks for a potential investor when compared with conventional fossil-based investments that have a track record of consistent returns. Unfamiliarity with technologies also plays a role, particularly in developing and emerging markets where green growth needs are particularly high. Green technologies often have higher capital costs, especially during the earlier stages of development, which can further deter investors.

An emerging body of experience suggests considerable potential exists for closing the green investment gap by mobilizing private finance through the targeted deployment of public finance. It is crucial to reform policies and incentives to give the right signals to investors, providing a strong enabling framework for investings. In parallel, private sector investment can be achieved by using a range of proven instruments and mechanisms to help reduce the cost of capital and investment risks.

Figure 2.1: Current and potential public-private finance mobilization to close the cost gap

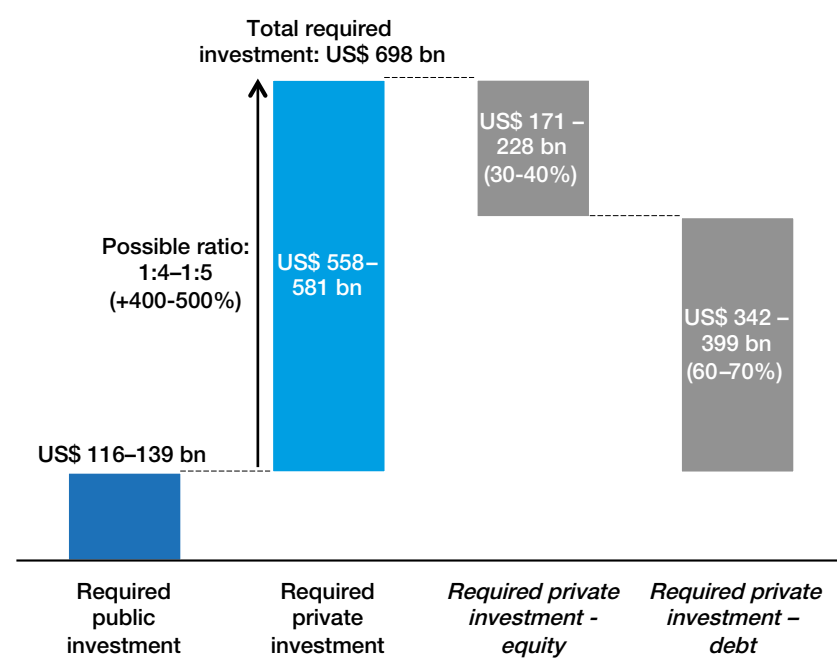

Note: The debt-to-equity ratio in Figure 2.1 is assumed at 70:30 based on the current average debt to equity ratio of clean energy asset finance projects according to Bloomberg New Energy Finance

\footnotetext{
s For a recent review of these issues see: Corfee-Morlot, J. et al. Toward a Green Investment Policy Framework: The Case of Low-Carbon, Climate-Resilient Infrastructure, Environment Directorate Working Papers, No. 48, Paris: OECD Publishing, 2012
}

While public-private finance mobilization and leverage ratios are difficult to calculate or compare across projects, countries and instruments, ratios of $1: 5^{t}$ and above are not uncommon, and there are some cases of instruments, such as grants, delivering ratios of $1: 8$ and higher.

To close the cost gap to support green growth through targeted public action, public investment would need to increase by $21-46 \%$ to US\$116-139 billion but could act to double current private-sector investment to US\$ 558-581 billion (Figure 2.1). This assumes that public finance has the potential to mobilize four to five times its contribution from private sources and that all of the public finance is leveraged at this average rate.

This chapter focuses on the instruments and mechanisms (Table 2.2) that public agencies can use to accelerate private investment in green growth by:

- improving the risk-reward calculus

- reducing the cost of capital

- providing prerequisites and enabling conditions

The analysis of initiatives and case studies (Table 2.1) highlights successful examples of finance mobilization throughout this chapter.

Table 2.1: Case studies analysed

\begin{tabular}{|c|c|c|c|c|c|c|}
\hline & Name & Country & $\begin{array}{l}\text { Public } \\
\text { investment }\end{array}$ & $\begin{array}{l}\text { Private } \\
\text { investment }\end{array}$ & $\begin{array}{l}\text { Total } \\
t \text { investment }\end{array}$ & Source \\
\hline 1 & $\begin{array}{l}\text { Mexico City's } \\
\text { Metrobus }\end{array}$ & Mexico & US\$287 m & US\$119m & US\$ 402 m & OECD \\
\hline 2 & $\begin{array}{l}\text { Walney Offshore } \\
\text { Windfarms }\end{array}$ & UK & $\begin{array}{l}\text { Incentive } \\
\text { mechanisms }\end{array}$ & $\sim £ 1,300 \mathrm{~m}$ & $\sim £ 1,300 \mathrm{~m}$ & $\begin{array}{l}\text { Climate Policy } \\
\text { Initiative }\end{array}$ \\
\hline 3 & $\begin{array}{l}\text { Ouarzazate } \\
\text { Concentrated } \\
\text { Solar Power Plant }\end{array}$ & Morocco & US $\$ 2,569 \mathrm{~m}$ & US\$253 m & $\begin{array}{l}\text { US\$ } \\
2,822 \mathrm{~m}\end{array}$ & $\begin{array}{l}\text { Climate Policy } \\
\text { Initiative }\end{array}$ \\
\hline 4 & $\begin{array}{l}\text { Energy efficiency } \\
\text { programmes in } \\
\text { Thailand }\end{array}$ & Thailand & $\sim$ US\$ $525 \mathrm{~m}$ & $\sim$ US $\$ 450 \mathrm{~m}$ & US\$975 m & $\begin{array}{l}\text { World } \\
\text { Resources } \\
\text { Institute }\end{array}$ \\
\hline 5 & $\begin{array}{l}\text { Solar water } \\
\text { heaters in Tunisia }\end{array}$ & Tunisia & US\$24 m & US\$110m & US\$134 m & $\begin{array}{l}\text { World } \\
\text { Resources } \\
\text { Institute/ } \\
\text { Climate Policy } \\
\text { Initiative }\end{array}$ \\
\hline 6 & $\begin{array}{l}\text { Wind energy in } \\
\text { Uruguay }\end{array}$ & Uruguay & $\sim U S \$ 7 \mathrm{~m}$ & $\begin{array}{l}\sim \text { US\$2,000 } \\
\mathrm{m} \text { (various } \\
\text { sources) }\end{array}$ & $\begin{array}{l}\sim \text { US\$2,000 } \\
\text { (estimated) }\end{array}$ & UNDP \\
\hline 7 & $\begin{array}{l}\text { The case of } \\
\text { watershed } \\
\text { protection in } \\
\text { Ecuador and } \\
\text { Colombia }\end{array}$ & Colombia & US\$30 m & $\sim$ US\$150m & $\begin{array}{l}\text { US\$170m } \\
\text { (estimated) }\end{array}$ & $\begin{array}{l}\text { World Water } \\
\text { Council }\end{array}$ \\
\hline
\end{tabular}

Full details of case studies are given in Appendix 2. Note that some investment sources given in the table may be estimated based on the designed financial structure and do not necessarily indicate achieved performance.

Indicating that US\$ 1 of public funding mobilizes a further US $\$ 5$ of private investment. 


\section{Public action and support can attract private investment by improving the risk-reward calculus}

Private investment in green technologies faces a number of risks:

Political risks include changes in government that affect the legal system, and the risk of civil unrest in certain countries.

\section{Macroeconomic risks include fluctuations in economic conditions and commodity prices, interest and exchange rates.}

Policy risks entail regulatory changes, such as those to feed-in tariffs or fossil-fuel subsidies that can alter a project's economic viability.

\section{Technology and operational related risks are those} intrinsically related to the technology in question. These range from performance-related risks, where revenues might be lower than expected, to risks resulting from the lack of or unreliable supporting infrastructure, such as electrical and water-grid networks.

Capacity risks refer particularly to development assistance and aid, where institutions and governments are unable to ensure funding is disbursed to projects and utilized.

Mobilizing private finance at scale requires that the risks of green investments be reduced to about the same levels as those faced by alternative, conventional investments (for example, in generating fossil fuel-based energy or environmentally suboptimal infrastructure). As shown by the case studies in the Appendix, development finance institutions, multilateral development banks, and domestic governments have successfully leveraged significant private investment through targeted support.

Table 2.2: A taxonomy of public instruments and mechanisms to create attractive green-growth investment conditions

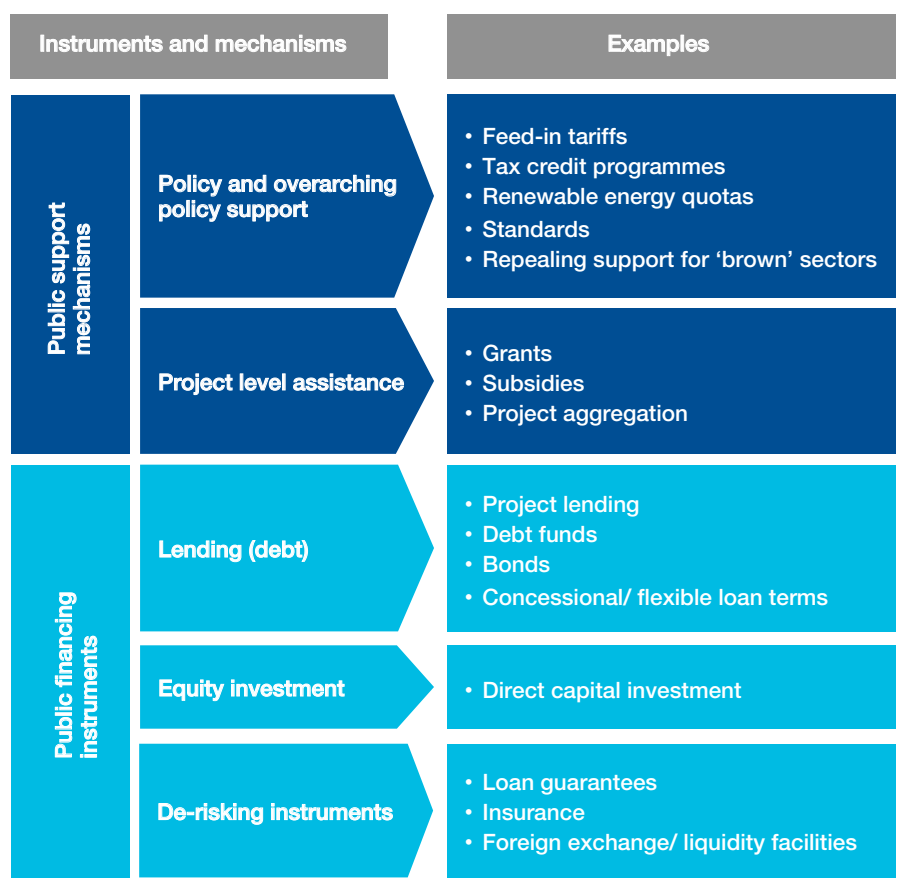

Source: Adapted from World Resources Institute, 2012

\section{Insurance and guarantees}

De-risking green investments to levels that are palatable to investors can be partially achieved by smoothing the investment landscape using guarantees and innovative insurance products. Political-risk guarantees are particularly useful in developing and emerging markets. The World Bank Group's Multilateral Insurance Guarantee Agency (MIGA) is one example of a political-risk insurance guarantee provider, having provided more than US\$ 24 billion in insurance coverage since 1988. Between 2005 and 2011, however, MIGA provided fewer than 10 guarantees for projects in 'green' sectors;, 64 and MIGA guarantees are not available for smaller and medium-sized investments.

Policy-related risks can be mitigated through regulatory risk insurance or guarantees. The US Overseas Private Investment Corporation (OPIC), for example, provides investors with financing, guarantees, political-risk insurance and support for private equity investment funds to help mobilize private capital. OPIC also offers regulatory risk coverage specific to renewable energy projects. The aim of this type of insurance/guarantee is to reduce the risk inherent in investing in non-conventional technologies, in non-conventional regions, and to create a level playing field for alternative investment choices ${ }^{65}$. Examples of risks covered could include material changes to feed-in tariffs, or revoking licences and permits necessary to operate a project. To scale up insurance solutions for green investment, it will be necessary to align interests, most likely with a public-private partnership between the insurance industry and various governments and regulators.

\section{Loan guarantees and partial risk/credit guarantees are} commonly provided by development finance institutions and have also proven useful in 'on-lending' arrangements where governments underwrite loans provided through intermediaries, such as commercial banks or state utility companies. In cases of default, the government agency or development finance institution can absorb some or all of the risk. This is particularly beneficial for new markets where private lenders are not initially comfortable or familiar with the technology in question.

Tunisia's Prosol Programme (see Appendix 2) is an example of debt default risk being removed from suppliers of solar water heaters. Commercial banks provided loans to customers through accredited suppliers, which were repaid through customers' electricity bills. Customers' services were withheld when they did not pay. The state utility acted as debt collector, enforcer and loan guarantor, shifting the credit risks from lenders to borrowers. This has improved awareness and expertise of commercial banks for renewable energy lending.

Work completed by the Green Growth Action Alliance highlights the potential role of partial credit guarantees in India to mobilize finance at scale, while in Kenya, the Alliance and the UNEP Finance Initiative are looking to design a Takeout Finance Facility to address the perceived asset-liability mismatch that has been identified as a bottleneck for private finance for renewable energy lending; local lenders often seem unable to lend beyond seven years while project developers seek 15-year loans.

There is significant potential for public sector and public financial institutions to provide more guarantees for higher-risk investments but guarantees alone cannot improve the commercial viability of all investment types. A combination of de-risking instruments is needed to bring investment risk down to acceptable levels. 


\section{Interest rate and currency facilities}

Where project developers need protection against macroeconomic risk and/or political volatility (for example, in emerging markets) interest rate and currency derivatives and facilities can reduce perceived risk. These are typically crossborder loans provided in the local currency that can protect the borrower from volatile fluctuations in the exchange rate, thereby avoiding repayments in foreign currency, and liquidity facilities, such as lines of credit that can inject short-term cash flow into projects, allowing the borrower to manage exchangerate fluctuations. Fees are usually required for interest rate and currency facilities, which reduce the overall economic viability of the investment. As a result, this mechanism is not often used in green investing. Government and financial institutions need to cooperate to provide these facilities at a lower rate or with no charge to encourage private-sector investment in countries where green growth is critically required but volatility in the local currency is high.

The private-sector facility of the United Nations Framework Convention on Climate Change (UNFCCC) Green Climate Fund (GCF), formally established as part of the Cancun Agreements in 2010, is one contender for providing interest rate facilities and guarantees to increase the capacity of banks and encourage increased lending for green projects. The GCF's mandate is to help developing nations limit or reduce their greenhouse gas emissions and adapt to the impacts of climate change. Its main role is to channel new, additional public financial resources from developed nations to affect private and public finance for mitigation and adaptation in developing countries. The privatesector facility of the Fund enables it to directly and indirectly finance private-sector mitigation and adaptation activities at international levels. The mandate is broad and could include a range of de-risking instruments to bridge the green technology cost gap, instruments such as subordinated debt (described below), risk guarantees and even equity ${ }^{66}$ among others.

Development financial institutions (DFls) play an important role in underwriting loans and offering liquidity facilities at concessional rates to reduce macroeconomic risk. The Japan Bank for International Cooperation (JBIC) provides loan guarantees for the co-financed portion of green projects. In 2010 and 2011, JBIC's Green Initiative provided an estimated US\$ 300 million in loan guarantees to local development banks for four renewable energy projects in Asia and South America ${ }^{67}$. Development banks are typically more familiar with political risk and macroeconomic conditions in developing countries and as such are well-placed to increase access to underwriting facilities to scale up private-sector investment in these regions ${ }^{68}$.

\section{Public action and support can attract private investment by reducing the cost of capital of green growth}

Green technologies are often earlier in the development stage and not always commercially viable, making them more expensive and riskier ventures. The incremental cost gap between conventional and green investments needs to be justified and filled, especially at the earlier stages in technology development. The private sector will continue to be an increasing source of green finance while the public sector has tended to fill the incremental green cost gap through policy-support mechanisms, such as feed-in tariffs and subsidies. In the longer term, sustaining such public-sector subsidies is questionable given the current economic climate.
Optimal financing structures on a sectoral basis will ultimately depend on the context. For example, for energy investment, debt provision from banks will play a larger role, while for transport-sector investment, the public sector will need to provide loss-absorbing equity. As such, the public sector can reduce the cost of capital and provide incentives to invest through proven interventions.

\section{Lending}

Reducing the cost of capital by providing loans (debt) is the most common source of finance for up-front and on-going project costs. Low-cost debt (concessional finance) from DFls can provide debt at lower interest rates over a longer term compared with commercial bank loans and will play a significant role in distributing long-term green finance, particularly in developing countries $^{\mathrm{u}}$. Examples include the European Bank for Reconstruction and Development (Box 2.3) and the European Investment Bank. The European Investment Bank has dramatically increased its lending for wind and solar energy in particular in recent years and delivered 5.5 billion euros (about US $\$ 7.25$ billion) in 2011. Energy efficiency is also a critical sector, attracting 1.3 billion euros (US\$ 1.7 billion) of EIB's lending in 2011. DFls are also prominent in dispersing money from the Climate Investment Funds, which have been shown to mobilize significant amounts of co-financing from other sources (see Box 2.1), highlighting potential for scale-up.

The public sector has also provided loans through financial intermediaries such as commercial banks. This approach can increase the awareness and willingness to lend in newer or less-established markets. In Thailand, the government established a revolving fund (see Appendix 2) in 2002 to provide loans, grants and subsidies to promote energy efficiency. Commercial banks were able to use this funding for energyefficiency project loans. This not only encouraged the banks to lend in an emerging market but additional finance was also mobilized towards the projects. Through the revolving fund, financial-sector capacity has increased in the energy sector, and loans that have been used to fund capital projects have resulted in reducing peak load energy by more than 500 megawatts.

Mezzanine financing can also help strengthen a project's equity profile because of its lower repayment priority. Mezzanine finance provides a hybrid of equity and debt, and gives the lender rights to convert outstanding debt to equity. Dong Energy, for example, was one of the major investors in the UK Walney Offshore Windfarms case study (see Appendix 2). Dong Energy extended mezzanine lending facilities to other investors to help secure financing for the $£ 1.3$ billion (US\$2.1 billion) project. DFIs have also been flagged as potential providers of hybrid equity products that could fill critical financing gaps for project developers in new markets ${ }^{69}$. The Global Climate Partnership Fund, a public-private initiative, is an example of an innovative fund that provides mainly medium- and long-term financing for climate change mitigation projects, including mezzanine financing ${ }^{v}$.

Green bonds (Box 2.2) are another emerging source of finance, with an estimated market size of US\$ 174 billion $^{70}$, which can also help reduce capital costs of green investment and close the cost gap. 
Box 2.1: The Climate Investment Funds: progress from the one of the first clean investment funds

In September 2008, 10 leading industrialized nations pledged more than US\$ 6.1 billion to finance two Climate Investment Trust Funds (CIFs): the Clean Technology Fund (CTF) and Strategic Climate Fund (SCF). The funds were designed to provide financing for climate-related investment to combat climate change. They are disbursed as grants, highly concessional loans and risk-mitigation instruments ${ }^{71}$, and are administered through multilateral development banks (MDBs) such as the World Bank Group.

\section{Clean Technology Fund}

The CTF provides highly concessional financing targeted at large-scale, country-initiated low-carbon projects in the power sector (nearly two thirds of funding), the transport sector ( 14\% of funding) and for energy efficiency ( $20 \%$ of funding). CTF funds have mobilized an estimated US\$ 8 in co-financing for every dollar allocated from public sources (implying a ratio of $1: 8)^{72}$. As of September 2012, nine donor nations had pledged US $\$ 4.8$ billion to the CTF Trust Fund, and US\$1.9 billion was approved for 28 projects in 18 countries. This has led to cofinancing of US\$ 16.4 billion, of which US\$ 6.4 billion (40\% of total co-financing) is from private sources, with the remaining co-finance provided by governments, multilateral financial institutions and carbon finance. Taking a leverage definition of CTF funding to private sources of co-financing only, the revised ratio is 1:3.3. A further 66 projects are awaiting approval of US\$ 2.2 billion of funding, with expected additional co-financing of US\$18.2 billion ${ }^{73}$.

Summary of Clean Technology Fund investments and sources of co-financing (US\$ millions)

Co-financing

CTF funding
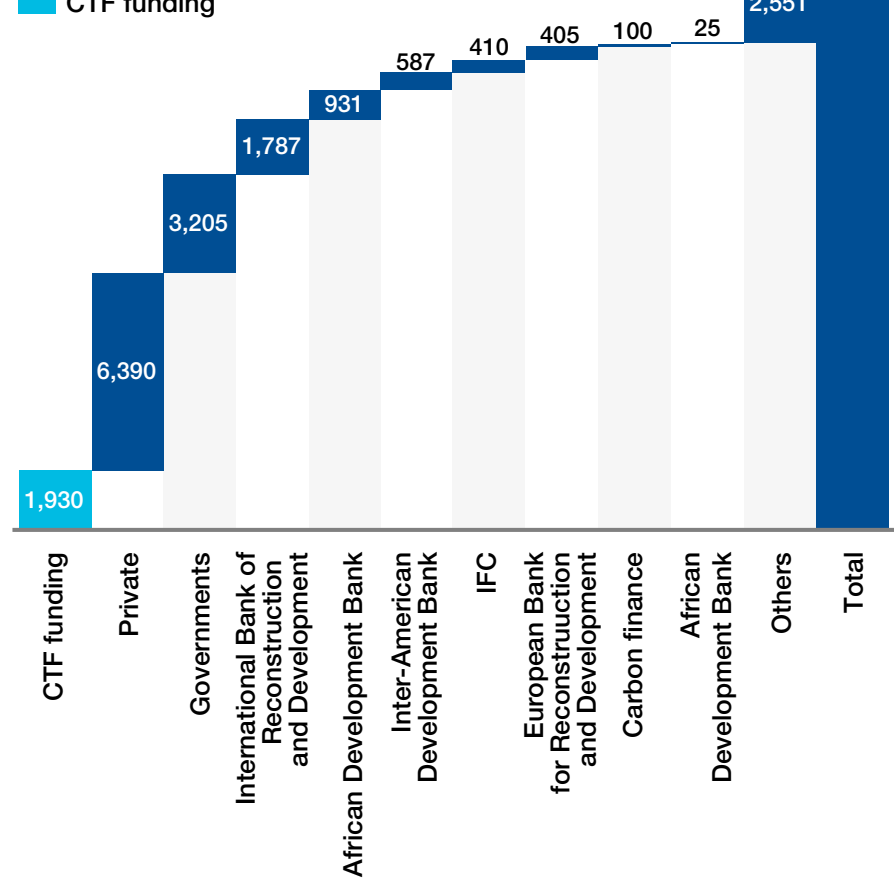

Source: Climate Investment Funds website

\footnotetext{
ATP, the Danish pension fund, has its own clean-energy fund, and some pension funds are establishing in-house infrastructure investment capabilities. For example AimCo, the Alberta Investment Management Corporation, and Calpers, have both invested directly in infrastructure projects in the past year.
}

\section{Strategic Climate Fund}

The mandate of the SCF is broader: to provide support for various programmes to test innovative approaches to climate change. The goals of the $\mathrm{SCF}^{74}$ are to:

\section{provide experience and lessons through learning by doing \\ - channel new and additional financing for climate-change mitigation and adaptation}
provide incentives for scaled-up and transformational action in the context of reducing poverty
provide incentives to maintain, restore and enhance carbon- rich natural ecosystems, and maximize the benefits of sustainable development

As of September 2012, US\$2.2 billion had been pledged from 13 donors for the SCF. To date, 95 projects have been approved across the three programmes, totalling US\$ 383 million in grants and near-zero interest credits. Funding from the SCF is expected to leverage an additional US\$ 1 billion in co-financing from other sources, implying a leverage ratio of 1:2.6.

\section{Box 2.2: Green bonds, projects bonds and institutional investors}

Green bonds can be used to raise capital to finance, or refinance, investments in low-carbon or otherwise environmentally beneficial projects. Like conventional bonds, green bonds can be issued by a corporate, bank or government entity. The size of the green bond market has been estimated at US $\$ 174$ billion $^{75}$ by HSBC and the Climate Bonds Initiative, under a definition that looks beyond explicitly labelled 'green/climate bonds'. Other estimates, including those from the OECD, place the market nearer to US\$ 86 billion ${ }^{76}$.

Green bonds are widely believed to have significant potential as a means to access deep pools of relatively low-cost capital that is held by institutional investors for green and climate changerelated projects. These investors typically avoid direct investment in green infrastructure and have historically preferred to invest via private equity-style infrastructure funds or through the listed debt or equity of infrastructure companies and developers. There are, however, an increasing number of exceptions ${ }^{w}$ to this rule where pension funds have invested directly and brought the skills to do so in-house. Alongside this trend, institutional investors are often seen as natural buyers of green bonds, given their appetite for investment in low-risk, fixed-income products with long-term maturities that match their long-term liabilities. Institutional investors, however, often lack the means to gain exposure to the green infrastructure market, but with a credit-rated and potentially liquid green bond market, institutional investors could potentially channel far more funds into the sector.

Project bonds are a specific and relatively small subset of the larger green bond market. Project bonds provide a means for infrastructure project developers to attract long-term debt financing from the international or domestic bond markets. This can be done by creating a special purpose vehicle, supported by a degree of equity from a sponsor (often pooled from project developers). Based on an assessment of the financial viability of the underlying projects, a credit rating can be secured for the vehicle, and if it is sufficiently high, bonds issued.

Bond finance raised through these means can be cheaper than commercial loans and non-recourse project-finance options. This can be a significant advantage for clean-energy projects where financing can represent a significant proportion of overall costs. Project bonds also provide an important opportunity to recycle limited quantities of construction capital through refinancing projects. 


\section{Equity}

Public action to either take an equity stake in projects or create attractive investment conditions for potential equity providers can help raise additional capital through other financing mechanisms by absorbing potential losses to other financiers. Direct equity investment from the public sector can be valuable for projects with heightened technology risks (those, for example, at an earlier stage of development or at the precommercial stage). This will be critical in markets with higher risk where the appetite for lending is limited.

Pension funds have also been mobilized as a source of private finance through careful risk allocation (as seen in the case of Walney Offshore Windfarms in the UK). With US\$ 71 trillion of assets under management in the OECD in $2011^{17}$, institutional investors are a potentially important source of finance for green growth. Successfully mobilizing institutional funds in equity injections can be achieved through complex financial engineering by providing the investor with a 'quasi fixed-income position', for example, by sharing the benefit of public financing incentives (such as feed-in tariffs) in renewable-energy projects. A fixed-income position can provide the investor with long-term returns in line with their investment strategy and risks. Opportunities exist to develop green projects with long-term returns that can attract institutional investors but the public sector needs to support this through improved policy frameworks.

\section{Prerequisites for private-sector finance are required to support green growth}

Public support is required for overarching policy support (renewable energy quotas, feed-in tariffs, eliminating fossil-fuel subsidies and other perverse incentives) and project level assistance. The latter includes grants, subsidies and technical assistance, all of which have been critical to the success of green infrastructure projects, as highlighted through case studies. Grants often achieve significant 'leverage' due to the relatively small initial tranche of funding needed for feasibility and commercial studies at project conception, while subsidies and incentives have been crucial to the success of many large renewable energy plants.

The Ouarzazate Concentrated Solar Power (CSP) Plant in Morocco (see Appendix 2) is an example of how policy support helped generate investment in a non-commercially viable technology. A substantial subsidy from the government of US\$ 1.2 billion, in the form of a Power Purchase Agreement above grid price covering the 25-year lifetime of the project, enabled the development of the project. The government and other sponsors are betting on the project contributing to the development of a CSP market that will bring longer-term benefits and economic returns.

In the case of the Walney Offshore Windfarms, the £1.3 billion project would not have been possible if not for the benefits provided by tradable green-energy certificates. These are expected to provide $60 \%$ of total project revenues worth £1.3-1.5 billion (US\$2.1-2.4 billion) over the lifetime of the project, paid by regional energy suppliers through the United Kingdom Government's Renewable Obligation Certificate scheme.
'Wheeling and banking' is another support mechanism that has brought success in India for wind energy. 'Wheeling' (electricity transmission and distribution) charges can be reduced to provide incentives for excess power to be fed back into the grid. When plants deliver more output than required - during high winds, for example - excess generation can be 'banked' with the transmission and distribution company. During low-wind seasons, the excess units are then drawn on.

Another policy tool that has been useful in reducing publicsector costs is 'reverse auction', whereby bidders compete to supply a service (such as electricity generation) at the lowest rates. The lowest rate is chosen as the default rate, keeping incentive costs lower for the public sector ${ }^{78}$.

Grants are often combined with technical assistance to maximize the impact of early-stage investment and also knowledge transfer. The Global Environment Facility (GEF) is the world's largest public funder for environmental projects. Since 1991, the GEF has provided US\$10.5 billion in grants, which has mobilized a further US\$ 51 billion in co-financing for more than 2,700 projects in more than 165 countries. Successful projects such as Mexico City's Metrobus project, wind energy development in Uruguay and watershed protection in Ecuador and Columbia (see Appendix 2) used GEF grant funding for technical assistance and advisory support to help encourage private-sector investment by creating national policy frameworks for green growth.

Technical assistance (Box 2.3) combined with finance from development banks and other lenders have helped promote market awareness among consumers, build the capacity of local institutions and train local staff, and develop and manage local green and climate-policy development. In Uruguay, for example, a joint project between UNEP and the Global Environment Facility provided a US\$ 1 million GEF grant for technical advisory support around policy de-risking measures to address multiple barriers in the wind-energy market. As a result 40 megawatts of wind energy is now installed, and based on the policies developed using the grant/technical assistance resources, a further 880 megawatts of wind contracts are in the pipeline.

In 2011, only US\$ 10-16 billion was provided in grant funding for climate-related investment, or $3 \%$ of flows ${ }^{79}$. Scaling up grant funding offers a big opportunity, given the high mobilization of co-financing possible and the policy development support that it can provide.

Research from the World Resources Institute has shown that pre-investment activities can create attractive investment conditions for scaling up investment for green growth. The Institute provides a framework ${ }^{80}$ for allocating public finance for pre-investment, highlighting that early actions are needed to address various barriers, improving the effectiveness of public finance to strengthen policy and institutional conditions, and industry and financial sector conditions. 


\section{Box 2.3: Combining technical support with lending for energy efficiency: highlights from the European Bank for Reconstruction and Development (EBRD)}

The EBRD supports green growth through its Sustainable Energy Initiative (SEI), which was launched in 2006 with the aim of scaling up sustainable energy investments, improving the business environment for sustainable investments and working closely with donors to develop effective measures to address barriers to market development. To date, the EBRD has financed more than 550 SEl projects in 31 countries, amounting to an SEl volume of more than 10 billion euros (about US $\$ 13.2$ billion) and a total project value of more than 50 billion euros (about US\$ 66 billion). Emission reductions achieved though these projects are estimated at 50 million tonnes of $\mathrm{CO}_{2}$ per annum, higher than the annual emissions of Hungary in 2010 and equivalent to almost $1.4 \%$ of the total emissions of the EBRD region.

To achieve this, the EBRD has developed a unique business model to finance sustainable energy projects, combining investments with technical assistance and policy dialogue. Technical assistance, which has amounted to 187 million euros (about US\$ 246 million) since 2006, includes various activities, ranging from market analysis and energy audits to training and raising awareness. As part of its policy dialogue activities, the SEl works with governments to help develop strong institutional and regulatory frameworks that provide incentives for sustainable energy investments. The combination of these three activities provides strong support for sustainable energy investments.

An industrial project financed by EBRD in Ukraine showed how US\$150,000 of donor funding for energy audits at the client resulted in loan financing totalling US\$ 55 million, of which US\$ 27 million was dedicated to energy-efficiency measures identified in the audits. For energy efficiency finance only, the leverage on the donor funds was 1:187.

To enable projects such as these, the EBRD has established an in-house energy efficiency and climate change team consisting of more than 30 specialists, including engineers, finance specialists and policy experts. This team works directly on projects with bankers and clients, and manages technical assistance projects for capacity building, technical advice, project implementation support and improving the investment climate for energy efficiency and renewable energy through policy dialogue.

\section{Private leverage achieved by different instruments varies depending on the definition and context}

Public investments need to deliver extra financing from the private sector and environmental and social benefits from the project. Public actions, as summarized above in the form of technical assistance and capacity building, need to create an attractive investment environment. The effectiveness of such public actions in mobilizing additional finance cannot be easily measured but when it comes to determining the efficacy of alternative tools and mechanisms, assessing private finance mobilized can shed some light on where resources could be best allocated based on past performance (Table 2.3).
To measure the success of public financing interventions to 'crowd in' private funding, lenders and public institutions can measure additional co-financing produced as a result of their investment by determining the 'leverage ratio'. Methodologies to determine leverage differ and there is no one consistent definition available, often because the goal of what is being measured changes from organization to organization. Two critical methodological concerns arise from determining leverage:

1. the 'additionality' of financing: whether private investment would be deployed irrespective of the public finance support

2. co-financing: which sources of finance are used in the leverage calculation; for example, private sources only or further public sources

The OECD assessed 50 green investment projects and concluded that depending on the methodology deployed, leverage factors ranged from 1:0 (no leverage) to 1:78 (extremely high) ${ }^{81}$. Leverage factors varied widely depending on the technology, mechanism used and region of investment. Public funds often do not leverage private investments but come as a windfall profit, crowding out private funds, and high leverage does not necessarily equate to a large impact (such as emissions reduction or positive social gains). A stricter and more functional common definition and methodology for leverage of private investment is needed to measure the effectiveness of public interventions, and should take into account the benefits of private investment beyond the provision of capital (mitigation or adaptation benefits, for example).

More work is needed to understand the social and environmental benefits of deploying public finance, such as generating jobs or reducing greenhouse gas beyond mobilized private investment. High levels of finance mobilization do not necessarily mean high levels of environmental or social benefit.

\section{Table 2.3: Range of leverage factors achieved by instrument}

\begin{tabular}{lll}
\hline $\begin{array}{l}\text { Instrument/ } \\
\text { mechanism }\end{array}$ & $\begin{array}{c}\text { Leverage } \\
\text { achieved }\end{array}$ & Methodology \\
\hline Grants & $1: 8-1: 10$ & $\begin{array}{l}\text { UN High Level Advisory Group on } \\
\text { Finance methodology (debt financed } \\
\text { from grant funds) }\end{array}$ \\
\hline Clean Technology Fund & $1: 8$ & $\begin{array}{l}\text { CTF investment: other sources of } \\
\text { Co-financing (private, MDBs, etc.) }\end{array}$ \\
\hline $\begin{array}{lll}\text { Climate Investment } \\
\text { Funds (for private-sector } \\
\text { projects) }\end{array}$ & $1: 8.5$ & $\begin{array}{l}\text { Climate Investment Fund spending: } \\
\text { co-financing in private-sector }\end{array}$ \\
\hline $\begin{array}{l}\text { Global Environment } \\
\text { Facility grants }\end{array}$ & investments \\
\hline Carbon finance (CERs) $1: 7$ & $\begin{array}{l}\text { GEF grant: all other co-financing (public } \\
\text { and private) }\end{array}$ \\
\hline $\begin{array}{l}\text { Non-concessional } \\
\text { lending }\end{array}$ & $1: 2-1: 5$ & $\begin{array}{l}\text { CER revenue: total capital investment } \\
\text { Public spending: private capital raised } \\
\text { (UN High Level Advisory Group on } \\
\text { Finance methodology) }\end{array}$ \\
\hline $\begin{array}{l}\text { Climate Investment } \\
\text { Funds (public-sector } \\
\text { projects) }\end{array}$ & $1: 3$ & $\begin{array}{l}\text { Climate Investment Fund spending: } \\
\text { co-financing in private-sector } \\
\text { investments }\end{array}$ \\
\hline $\begin{array}{l}\text { Highly concessional } \\
\text { lending }\end{array}$ & $1: 1-1: 1.5$ & $\begin{array}{l}\text { MDB lending: other sources of } \\
\text { co-financing (public) (IFC)y }\end{array}$ \\
\hline
\end{tabular}

Sources: Climate Policy Initiative ${ }^{83}$, IFC ${ }^{84}$, Climate Investment Funds website ${ }^{85}$

Note: The methodologies used to calculate leverage of the different instruments shown differ, and therefore individual ratios should not be compared with one another.

Leverage ratios achieved under alternative methodologies have been shown to be higher but this figures is an adjusted average to include only mobilized funds that were not already earmarked for climate finance (Source: Is there a leverage paradox within climate finance? 2011. Cambridge, United Kingdom: Climate Strategies).

This is for International Development Association-type (public) loans, since highly concessional loans are rarely available to the private sector. 
Carbon finance, through the monetization of Certified Emission Reductions (CERs) and Emission Reduction Units (ERUs) and voluntary carbon offsets, has provided an important incentive for climate-change mitigation projects in both developed and developing countries. Since the Kyoto Protocol came into force in 2005, more than 4,500 Clean Development Mechanism (CDM) projects have been registered with the United Nations Framework Convention on Climate Change (UNFCCC), with a further 4,300 in the pipeline ${ }^{86}$.

At the end of 2011, US\$28 billion worth of pre-2013 CERs had been contracted forward. If all underlying projects are implemented, these contracts will have supported additional investments of more than US\$130 billion in developing countries $^{87}$. Research from Climate Strategies ${ }^{88}$ suggests that the CDM mobilization ratio is in the range of 1:3-1:4.5 after adjusting the leverage definition to include only mobilized funds that were not already earmarked for climate finance.

Project-based markets have suffered as a result of the economic recession and the uncertainty around the future of the Kyoto Protocol. The total market value of CDM finance as an incentive has more than halved since its peak in $2007^{89}$. Governments need to keep the momentum high by pushing for new binding reduction targets to drive continued climate-change mitigation investment in emerging economies.

\section{A number of existing instruments and mechanisms demonstrate high mobilization of private funds through targeted public support}

A review of project case studies, initiatives from members and partners of the Green Growth Action Alliance and the past performance of different mechanisms and instruments has demonstrated how different interventions can create attractive investment conditions for the private sector, and enable targeted public investment for green-growth projects. The following lessons for good practice have emerged:

\section{Targeted government support is crucial to unlock commercial green finance}

All case studies showed that initial support and backing from the public sector is an important prerequisite for mobilizing private funds. In the case of Metrobus in Mexico City, such support also included the presence of a champion/leader to advance policy and negotiate complex public-private partnerships. The lack of leadership in some projects resulted in delays. Dialogue with the private sector, stakeholder engagement and capacity building are all examples of government support that enabled the projects to develop.

\section{Overarching policy support enabled most projects to attract private-sector involvement}

Governments need to develop investment-grade national policy frameworks to create a supportive business environment that enables attractive returns for investors in green technologies. Not surprisingly, policy support via national legislation, such as for renewable energy targets and frameworks, emissionreduction targets and subsidy programmes, has created new green markets and ensured projects' commercial viability. The largest injections of private finance - for the Walney Offshore Windfarms in the UK, for example - would not have been provided if it were not for the incentive frameworks provided by the government through green tradable energy certificates.
Public interventions can be successful when tailored to local requirements, involving end-users

The most innovative examples of public interventions, such as scrapping incentives for old bus fleets in Mexico city to remove competition to greener transport, and 'on-lending' through state utility companies by commercial banks to make it easier for customers to pay for energy efficiency measures in Tunisia, were tailored to local contexts to minimize risks and enable sustained private investment. With households already providing almost $10 \%$ of overall climate-finance flows ${ }^{90}$, there appears to be significant potential to scale up private investment.

\section{Early-stage funding and grants can mobilize private finance}

In almost all cases, funding from public sources, such as the Global Environment Facility and Clean Technology Funds, to pay for initial research, feasibility studies, capacity building, policy design and technical assistance, was a core catalyst for further private-sector investment. Grant funding, when used effectively (for example, in Uruguay to develop Independent Power Producer legislation and national renewable energy targets), can pave the way to new green market creation and remove impediments that previously deterred private investors. Subsidies and grants can lead to high leverage of private funds, especially when combined with technical assistance; those given by EBRD's lending programme for energy efficiency, for example. More needs to be done by governments to make clean investment funds such as the CTF more readily available and accessible. Carbon-offset financing (Box 2.4) can also play a more important role in the future, buffering risk for investors, as evidenced in projects such as Metrobus.

\section{Investment capital can be de-risked through innovative models}

The private sector will not scale up financing for green investments unless the risks of investing are no more pronounced than those for conventional investments. Case studies have shown that large private-sector investment has been successful in green projects when risks levels were reduced to acceptable, normal levels. De-risking tools, such as guarantees and insurance against policy, regulatory and macroeconomic risk, are underused and offer significant potential for mobilizing private investment. Work by the Green Growth Action Alliance in Kenya has shown promise in developing technological risk insurance for early-stage investment in geothermal technologies, while in India, partial credit guarantees have the potential to realize up to six times their investment in private-sector funding for solar power development. Innovative approaches have also emerged to promote commercial lending for green projects in developing and new markets, through support from governments and international financial institutions to underwrite loans. This is particularly beneficial in markets where a lack of familiarity with the technology in question and fears of debt default would otherwise make lenders less willing to release funds to scale up investment. 


\section{Part 3: Catalysing Leadership and Private Investment}

\section{Green investment can be scaled up to deliver sustained global growth}

This first Green Investment report synthesizes, crystallizes and draws out key implications and recommendations from the best available research on green investment from Alliance members and other leading institutions. Based on current analysis on global green investment flows and the amounts needed to address climate and other environmental challenges, and given the growing base of experience in targeting public funds and policies to attract private investment in green growth, there are four recommendations for government, business and public finance leaders.

1. Greening investment, and thereby the economy, is the only option: carbon and resource-intensive growth is simply not a viable growth pathway

This first message is a broadcast to political, business, labour and civil society leaders and the general public. Economic growth cannot be sustained without dramatic increases in natural resource productivity and reductions in carbon emissions. As a result of the clear evidence of negative climate change impacts today, and the potentially devastating impacts in the future, greening investment is a pre-condition for a stable, vibrant and inclusive global economy. Building from the 2012 G20 Summit, G20 leaders should reaffirm that greening the economy is the only route to sustained growth and development.

\section{Transitioning to a green growth pathway is achievable at} low cost

Closing the gap between current investment flows and what is needed to achieve sustainable growth is completely achievable. The incremental costs of greening growth are insignificant compared with the costs of inaction, with fuel savings compensating in large part for the investment requirements. However, there are key barriers that must be overcome, from institutional inertia to first-mover disadvantages and a resistance to change. Political and business vision and leadership is needed to transform the business-as-usual investment pathway from traditional fossil-based infrastructure to low-carbon solutions.

To accelerate and guide the green growth transformation, governments, investors and international organizations must improve global tracking, analysis and promotion of green investment. While considerable progress is being made through the individual and collective efforts of many institutions, there is a pressing need to extend data and methodologies to include the broader dimensions of green investment needs, including agriculture, water, and transportation infrastructure requirements.
3. Effective policy pathways and the efficient deployment of public finance to green investment is well understood, tried and tested, and must now be scaled up

On public policies, whilst there is always more to learn, there is a broad consensus on what needs to be done. Part 2 of this report illustrates some of the many ways and means that can close the green investment gap. There is a need to reinforce the collective political will to advance public policies to incentivize green investment and economic growth, including:

accelerating the implementation of the G20 commitment to phase out fossil-fuel subsidies, and bringing into force fiscal and other instruments that establish robust carbon prices

enabling greater free trade in green technologies, including those developed with commercial and public finance, through initiatives such as those adopted by APEC (Asia-Pacific Economic Cooperation) leaders

- integrating the adaptation agenda into green investment by supporting initiatives that promote the scaled-up deployment of clean energy, water and agriculture across poorer communities, as exemplified by the United Nations Sustainable Energy for All Initiativez.

On public finance, historically low interest rates and the need to kick-start the global economy are the perfect conditions for mobilizing and investing public finance in green infrastructure that will serve the needs of long-term, sustainable growth. There is sufficient experience in using financial instruments to enable public finance to be used to balance the mobilizing of private finance with public-sector risk-taking. To this end, G20 governments and emerging economies can demonstrate leadership by:

encouraging development finance institutions to accelerate and rationalize the broad adoption and scaleup of tried and tested public financing instruments, such as those that reduce investment risks for the private sector. The International Development Finance Clubaa is well-positioned to lead this agenda.

engaging private investors directly in debate, co-design and wider dissemination of experience of relevant cofinancing mechanisms. More public-private collaboration is needed to explore how best to accelerate investment in green infrastructure; this can inform the design of the next generation of catalytic green funds, such as the Green Climate Fund being developed for the United Nations Framework Convention on Climate Change. 


\section{Investors should seize the green investment opportunity by calibrating risk-return analysis to the current climate in pursuit of long-term returns}

Investors are increasingly looking to diversify their portfolios and exploring unconventional assets for returns. Throughout the investor community, infrastructure investment is attracting attention as a potential source of stable returns. Private investors do not need to wait for public policies or subsidies to remove all material risk. The rapid pace at which green solutions are developing is an ideal opportunity for investors to enter a growing market. With investor leadership_perhaps facilitated by the new Global Investor Coalition on Climate Change ${ }^{\mathrm{bb}}$--there are a number of tried and tested public-private collaborations that can be expanded upon. Actions to be taken by private investors include:

- enhancing financial analysis of green investment opportunities by building on the experience of first mover investors,

factoring in more explicitly the risks of climate change and the potential for stranded, natural resource intensive assets.

- making greater use of proven public-private financing mechanisms to de-risk investments.

- Strengthening the appetite of developing country public finance agencies and investors in green investment opportunities, by adapting the financial and policy mechanisms outlined in this report.

The recommendations above will be advanced through the Green Growth Action Alliance, while the related initiatives outlined above and progress reports will be provided in future reports for the G20 and other stakeholders (see Box 3.1).

\section{Box 3.1: The Green Growth Action Alliance: combining public and private expertise to scale up investment for green growth}

The Green Growth Action Alliance is supporting the scale-up in green growth through the collaboration of more than 50 leading financial institutions, corporations, governments and nongovernmental organizations. By bringing together the knowledge of many different stakeholders, the Alliance aims to work with governments to help them adopt a systematic approach that rewards innovative green sectors through sound policies and improves their access to finance. Alliance members aim to achieve this by: collaborating to identify and deploy public money that can be used to unlock and utilize private-sector investment; identifying innovative financing and de-risking structures; supporting pilot testing of new models; and feeding results into international processes.

Some examples of initiatives and working groups trying to achieve these goals are given below.

\section{Development and testing of new financing tools}

In India, the Alliance worked with the Asian Development Bank, the Clinton Climate Initiative and the United Kingdom Government's Capital Markets Climate Initiative to design and test public financing structures to mobilize private finance for India's solar sector. This initiative resulted in the Renewable Energy Certificate Financing Facility designed to give private lenders confidence that debts can be repaid and to reduce the marginal cost of financing. The Alliance is also helping to unlock private financing for clean energy in Kenya by exploring bottlenecks to deploying private finance. Specific models being developed through this process include a bespoke insurance product for early-stage geothermal drilling risk, and a Policy Risk Insurance Mechanism for small- and medium-sized enterprises.

\section{Promotion of green free trade}

Removing trade barriers will promote free trade in green goods and services, accelerate green technology deployment, spur competition, innovation and job creation, and reduce the cost of energy. Recent progress has been made by APEC (Asia-Pacific Economic Cooperation) leaders, with tariff reductions for green goods and services currently being negotiated ${ }^{91}$. More progress is needed, however. By working pro-actively with governments and civil-society organizations, the Alliance is developing solutions, such as possible new green free-trade areas.

Promotion of large-scale renewable-energy purchases by corporations

Corporations can boost confidence in renewable-energy projects by using their balance sheet, pooling funds or renewable-energy purchases and entering into long-term powerpurchase agreements directly with developers. The Alliance brings together corporate consumers, renewable-energy project developers and financiers to test and pilot end-user financing models in specific countries.

\section{Energy efficiency financing}

The Alliance is advocating for new financing models that deliver energy efficiency. It is drawing on the experience of member organizations and collaborating with national governments and prominent international platforms to incubate new models to increase the availability of private finance and to help produce a vibrant market for delivering efficiency measures; for example, through new funds for energy-service companies in Mexico and Russia.

\section{Climate-smart agriculture financing}

The Alliance is developing replicable models that produce private financing for sustainable agriculture. The first pilot is being conducted in Vietnam and has identified specific interventions, including: developing a local investment fund to promote forest protection; using renewable energy to reduce greenhouse gas emissions from agricultural wastes; developing irrigation infrastructure for improved land management; and technical assistance to local banks to help them identify and lend to smallholders that follow good environmental practices.

\section{Innovative finance models}

The Alliance is helping to shine a light on successful green investment models with potential for scale through its partnership with the UNFCCC Secretariat's Momentum for Change: Innovative Financing for Climate-friendly Investment initiative. The Alliance will note meritorious innovations, such as the models outlined in this report, and push for their recognition at future UNFCCC and World Economic Forum events so that they and other successful approaches might be replicated ${ }^{c c}$. 


\section{Appendices}

\section{Appendix 1: Assumptions and Data}

Sources Used in the Investment Gap Analysis

The below table outlines the sectors addressed in Part 1 of this report, as well as:

- the investment needs under a business-as-usual (BAU) and $2^{\circ} \mathrm{C}$ scenario

- any conversions and assumptions attached to the presented investment needs

- scope of investment needs (e.g. sectors, and regions, if not global)

- normalized values on a per-year basis between 2010 and 2030

- data gaps where additional investment needs under a $2^{\circ} \mathrm{C}$ scenario are unknown 


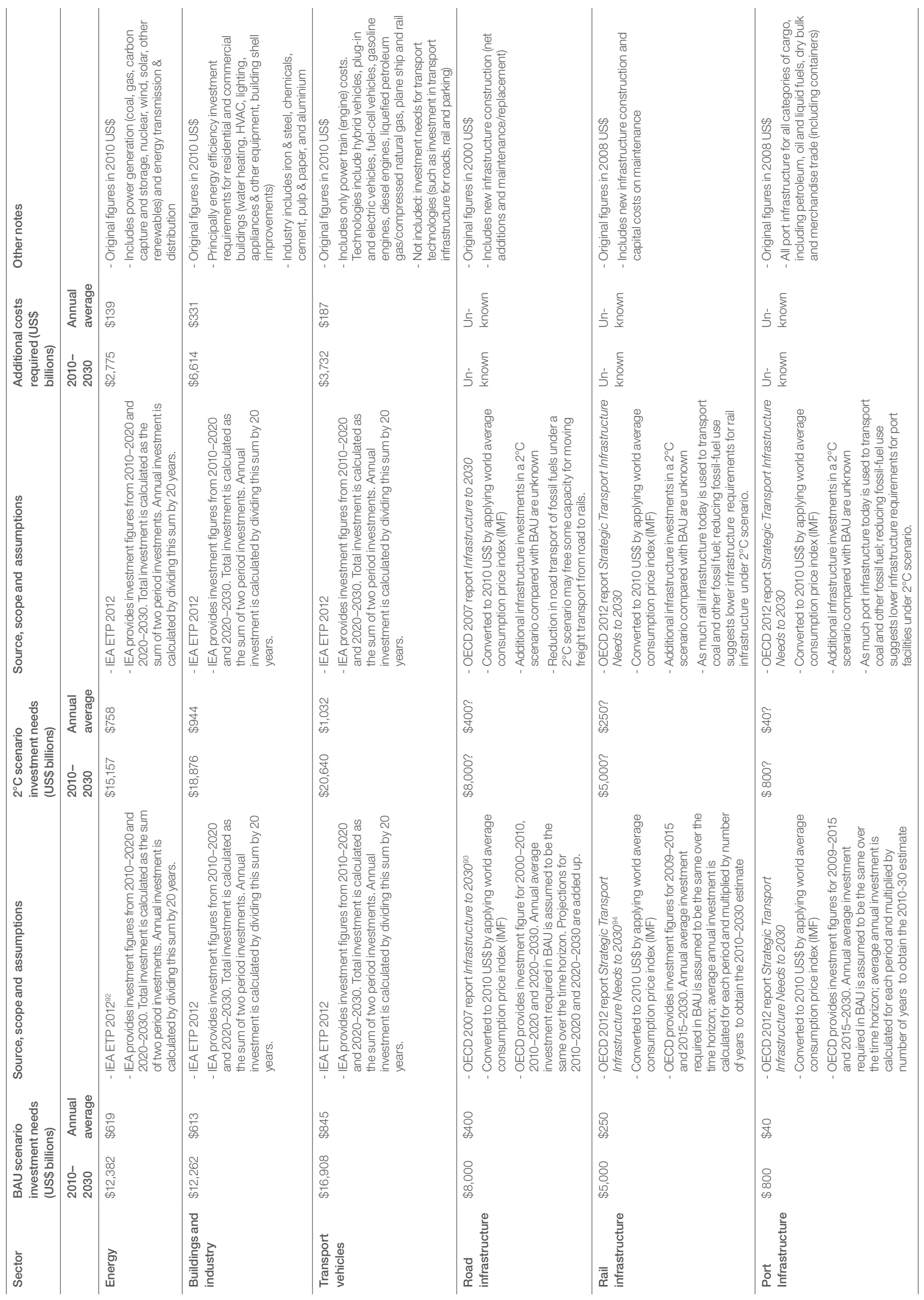




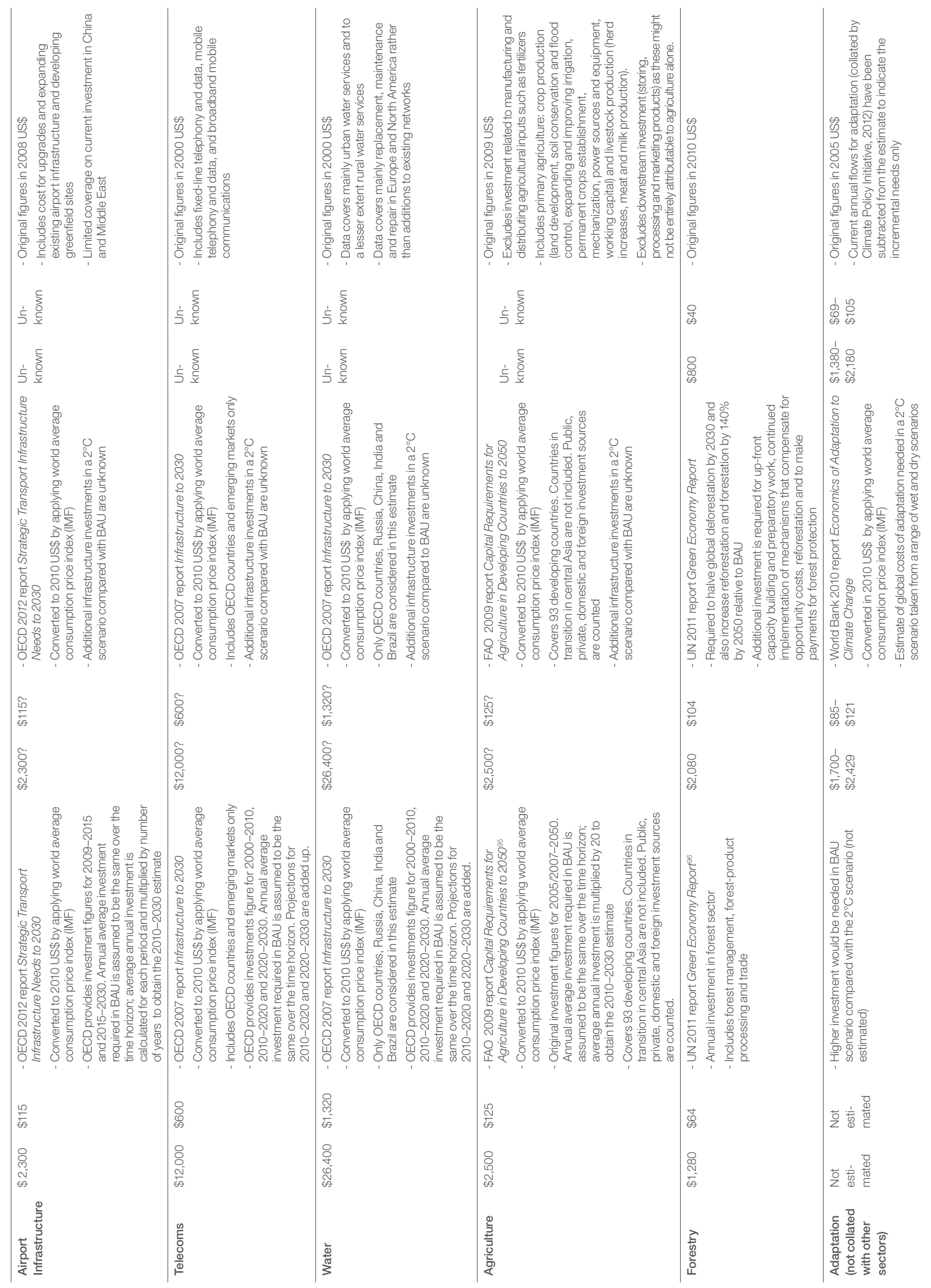




\section{Appendix 2: Case Studies}

Innovative partnerships can be developed through targeted government support: the case of Mexico City's Metrobus

\section{Case study and data provided by the OECD ${ }^{97}$}

\section{Overview}

Mexico City's Bus Rapid Transport (BRT) system is a surface metro system consisting of four lines covering $93 \mathrm{~km}, 365$ buses and a daily patronage of more than 700,000 passengers. It commenced in June 2005 and is still expanding. It has typical elements of a BRT system, including dedicated, confined bus lanes, enclosed stations, electronic fee payment prior to boarding, high-capacity buses and advanced control systems. It replaced an existing ineffective microbus network with higher social costs of safety and air quality. The Metrobus project succeeded despite an environment with multiple investment barriers, including a complicated concession scheme and lack of funding, and initially received little political support.

Mobilizing private finance

\begin{tabular}{l} 
Existing investment \\
barriers \\
\hline - Concession schemes \\
and strong concession \\
laws \\
- Absence of public- \\
private partnership \\
laws \\
- Lack of revenues to \\
cover large up-front \\
costs \\
- Highly centralized \\
nature of transport \\
planning
\end{tabular}

Underlying enabling Successful policies and factors instruments used

Strong lobbying from - Scrapping programme
civil society and for existing fleet non-governmental - Unbundling organizations clean-air

Presence of an effective champion

infrastructure and flee costs to attract more investors

- International grants for early-stage planning

Clean Development Mechanism (CDM) financing

Payments for Services scheme for private investor-operators

Lack of public-private partnership (PPP) law forced the development of innovative partnerships

Financing structure (US\$ millions)

\begin{tabular}{|c|c|c|c|c|}
\hline $\begin{array}{l}\text { Public } \\
\text { investment }\end{array}$ & Sources & $\begin{array}{l}\text { Private } \\
\text { investment }\end{array}$ & Sources & $\begin{array}{l}\text { Total } \\
\text { investment }\end{array}$ \\
\hline \multicolumn{5}{|l|}{ Infrastructure } \\
\hline $258 \mathrm{~m}(88 \%)$ & Mexican Government & 35 m (12\%) & Various & $293 m$ \\
\hline \multicolumn{5}{|l|}{ Fleet } \\
\hline 15 m (15\%) & Mexican Government & 84 m (85\%) & Various & $99 \mathrm{~m}$ \\
\hline \multicolumn{5}{|l|}{ Other funding } \\
\hline $9 \mathrm{~m}$ & $\begin{array}{l}\text { CDM financing (over } \\
10 \text { years)* }\end{array}$ & & & $9 \mathrm{~m}$ \\
\hline $4.8 \mathrm{~m}$ & $\begin{array}{l}\text { World Bank GEF } \\
\text { Grant }\end{array}$ & & & $4.8 \mathrm{~m}$ \\
\hline \multicolumn{5}{|l|}{ Total } \\
\hline $287 \mathrm{~m}$ & & $119 \mathrm{~m}$ & & $406 \mathrm{~m}$ \\
\hline
\end{tabular}

Exchange rate used as of 22 October 2012 (12.88 MXN/USD)

* Assuming US\$22/tonne in CDM revenue

Achieved leverage

Public : private leverage

Methodology

achieved

\begin{tabular}{ll}
\hline $1: 0.42$ & Overall public : private ratio \\
\hline $1: 19$ & CDM revenues : overall investment (Line 1 only) \\
\hline $1: 82$ & World Bank GEF Grant : overall investment
\end{tabular}

Lessons learned and scalable attributes

On-the-ground capacity support from a champion, nongovernmental organizations and civil society contribute to project successes.

- Perverse incentives can be reversed through government action, shown here through a unique scrapping programme for 'brown' infrastructure and granting equity in the new system to existing concessionaires.

- The lack of PPP law does not necessarily prohibit privatesector investment. The lack of PPP law in Mexico at the time created innovative partnerships between government and private-sector operators through a Decentralized Public Organism (DPO) that manages the Metrobus network.

Strong public incentives are needed to make large projects viable: the case of Walney Offshore Windfarms, UK

Case study and data provided by the Climate Policy Initiative ${ }^{98}$

\section{Overview}

The £1.3 billion (US\$2.1 billion) Walney Offshore Windfarms (WOW) is a 367.2 megawatt offshore wind park in the United Kingdom developed by DONG Energy. At the time of commissioning in 2012, it was the largest offshore wind park in the world. At the time of its approval in 2007 DONG Energy faced a serious challenge in attracting sufficient investment. The offshore location added numerous risks to the project profile, including significant revenue, construction, operation, and maintenance risks. Typical providers of project finance European banks - were reluctant to back such a large renewable energy project, especially given the escalating European debt crisis. The Walney project used a combination of policy and financial tools and incentives to successfully tackle barriers to renewable energy investment at this scale.

\section{Mobilizing private finance}

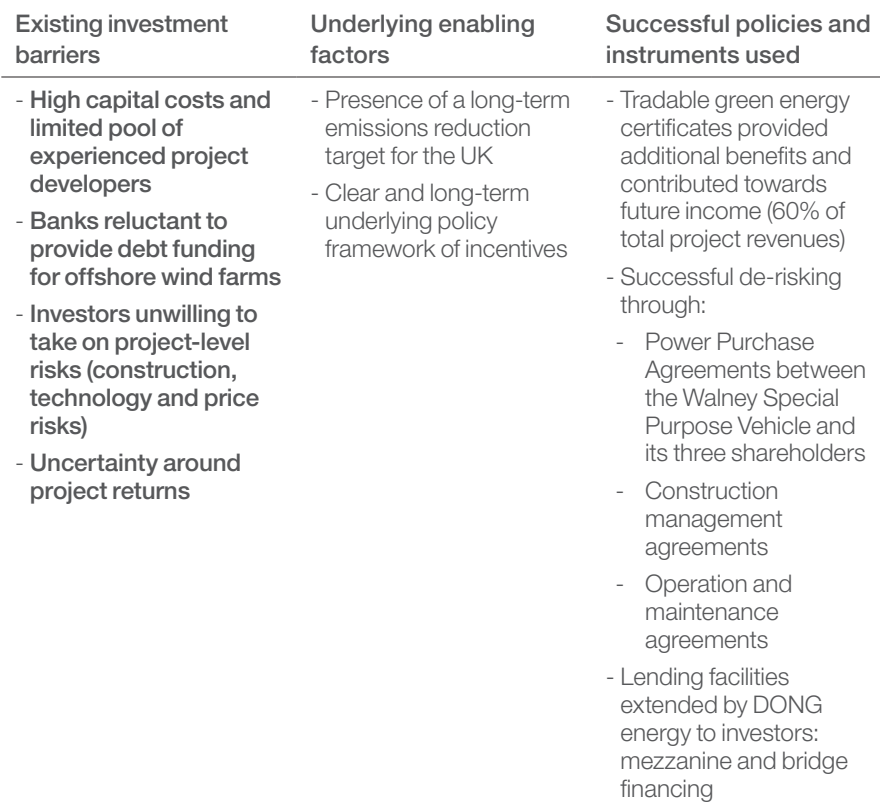


Financing structure (US\$ millions)

\begin{tabular}{ll} 
Private investment & Sources \\
\hline $\mathbf{5 0 . 1} \%$ & DONG Energy Power \\
\hline $\mathbf{2 5 . 1} \%$ & SSE Renewables \\
\hline $\mathbf{2 4 . 8 \%}$ & OPW HoldCo* \\
\hline
\end{tabular}

Total: $£ 1.3$ billion

* In 2010, the OPW joint venture, a dedicated special purpose vehicle jointly held by the Dutch pension fund PGGM and the Dutch private equity fund Ampère Equity Fund acquired a 24.8\% share in WOW from DONG Energy.

In addition to the $£ 1.3$ billion investment for WOW, revenue incentives through tradable green energy certificates worth another £1.3-1.5 billion (US\$2.1-2.4 billion) over the lifetime of the project will be paid by regional energy suppliers through the United Kingdom Government's Renewable Obligation Certificate scheme.

\section{Lessons learned and scalable attributes}

- De-risking the equity stake can attract non-traditional investors by matching the equity features of the project to those of common fixed-income securities.

- Attractive government policy incentives and the innovative use of incentives by project developers are essential to make the project viable to all stakeholders.

- Innovative financial engineering can shield external investors from major risks of clean-energy investments.

\section{Government subsidies can help push commercially unproven technologies into a more competitive market: the case of Ouarzazate Concentrated Solar Power Plant, Morocco}

\section{Case study and data provided by the Climate Policy Initiative ${ }^{99}$}

Overview

Ouarzazate I is a concentrated solar power (CSP) plant financed by the Clean Technology Fund, international finance institutions, the Government of Morocco and a consortium of private developers. The 160 megawatt Ouarzazate I Plant is the first phase of a 500 megawatt CSP facility in Morocco. It is the first project under the recent Morocco Solar Plan, which aims to install 2,000 megawatts of solar power capacity by 2020, including five CSP plants. The project will be developed via a public-private partnership by a special purpose vehicle, a consortium of private developers and the Moroccan Agency for Solar Energy (MASEN). The project is made possible by a substantial subsidy from the Government of Morocco in the form of a power purchase agreement above grid price covering the expected 25-year lifetime of the project. The Morocco Government and international finance institutions are betting on the project's contribution to developing a CSP market in the region that will bring longer-term and broader economic benefits. Construction of the plant was scheduled to start before the end of 2012.

\section{Mobilizing private finance}

\begin{tabular}{lll}
$\begin{array}{l}\text { Existing investment } \\
\text { barriers }\end{array}$ & $\begin{array}{l}\text { Underlying enabling } \\
\text { factors }\end{array}$ & $\begin{array}{c}\text { Successful policies and } \\
\text { instruments used }\end{array}$ \\
\hline $\begin{array}{l}\text { - High cost of CSP } \\
\text { compared with }\end{array}$ & - Clear national policy & - Significant government \\
framework and & subsidy to cover the \\
sources & dedicated agency to & difference between the \\
drive projects forward & grid price and actual \\
- Size of investment & - Significant involvement & cost of electricity \\
required exceeds & of international finance & production (i.e. \\
resources available & institutions & incremental cost) \\
from one single & - Close coordination and & - Power purchase \\
institution & strong engagement of & agreements to shift \\
- Institutionally complex & donors & revenue risk from private \\
infrastructure & & developer to the \\
investments with high & & Morocco Government \\
transactional costs & & - Concessional loans and \\
& & grants from multiple \\
& & international finance \\
& & institutions, including \\
& & through the Clean \\
& & Technology Fund, \\
& & substantially reducing \\
& & financing costs \\
& & - Public-private \\
& & partnership offering $75 \%$ \\
& & equity stake to a private \\
& & consortium \\
& &
\end{tabular}

Financing structure (US\$ millions)

\begin{tabular}{|c|c|c|c|}
\hline $\begin{array}{l}\text { Public } \\
\text { investment }\end{array}$ & Sources & $\begin{array}{l}\text { Private } \\
\text { investment }\end{array}$ & Sources \\
\hline $1,192 \mathrm{~m}$ & $\begin{array}{l}\text { Government subsidy (covering } \\
\text { incremental cost of electricity } \\
\text { production) }\end{array}$ & $253 m$ & $\begin{array}{l}\text { Equity from private } \\
\text { investors ( } 75 \% \text { stake } \\
\text { of public-private } \\
\text { partnership) and } \\
\text { public agency (25\%) }\end{array}$ \\
\hline $998 \mathrm{~m}$ & $\begin{array}{l}\text { Concessional loans (IBRD, } \\
\text { EIB, AFD, KfW/BMZ, AfDB) }\end{array}$ & & \\
\hline $197 \mathrm{~m}$ & $\begin{array}{l}\text { Clean Technology Fund loans } \\
\text { (AfDB, IBRD) }\end{array}$ & & \\
\hline $182 \mathrm{~m}$ & $\begin{array}{l}\text { Grants (EC/NIF, KfW/BMU, } \\
\text { GoM, MASEN) }\end{array}$ & & \\
\hline \multicolumn{2}{|c|}{ Sub-total: 2,569 m } & \multicolumn{2}{|c|}{ Sub-total: $253 \mathrm{~m}$} \\
\hline Total financi & g mobilized: $2,822 \mathrm{~m}$ & & \\
\hline
\end{tabular}

Achieved leverage

\begin{tabular}{ll}
$\begin{array}{l}\text { Public : private leverage } \\
\text { achieved }\end{array}$ & Methodology \\
\hline $1: 1.4$ & Government subsidy : All other leveraged money \\
\hline $1: 15$ & International grants: All other leveraged money \\
\hline
\end{tabular}

Lessons learned and scalable attributes

- There is no low-cost first step for technology that is not yet commercially viable. Concessional loans and public grants are, therefore, a crucial required element of finance for technologies such as CSP. Public money should, however, help to drive down costs and maximize potential future public benefits. As technologies develop, the appropriate level of public subsidization needs to be revaluated.

- Strong public support and closely aligning public partners are a prerequisite for project success.

- Public-private partnerships need to be carefully designed with a competitive tendering procedure to efficiently allocate risk. 
Funds raised through taxing fossil fuels can be used to leverage additional finance: the case of energy efficiency programmes in Thailand

\section{Case study and data provided by the World Resources Institute ${ }^{100}$}

\section{Overview}

The Government of Thailand established an Energy Conservation Promotion Fund (ECPF) in 1992 to raise funds for energy efficiency through a dedicated sales tax levied on petroleum products that was intended also to reduce demand for fossil fuels. The fund was established to provide loans, grants and subsidies to promote energy efficiency. A separately funded demand side management (DSM) plan was initiated by the Electricity Generating Authority of Thailand supported by the World Bank and funding from the Global Environment Facility (GEF), Australia and Japan. The plan exceeded its own targets and resulted in a peak-load reduction of more than 500 megawatts and cumulative annual energy savings of more than 3,000 gigawatt hours over seven years. In 2002 the Government set up a revolving fund that provided credit lines to banks for energy-efficiency project loans that was successful in strengthening financial-sector capacity and leveraging additional finance. Thailand's energy-efficiency reforms have been largely government-driven and financed but with strong strategic support from international partners.

\section{Mobilizing private finance}

\begin{tabular}{|c|c|c|}
\hline $\begin{array}{l}\text { Existing investment } \\
\text { barriers }\end{array}$ & $\begin{array}{l}\text { Underlying enabling } \\
\text { factors }\end{array}$ & $\begin{array}{l}\text { Successful policies and } \\
\text { instruments used }\end{array}$ \\
\hline \multirow{3}{*}{$\begin{array}{l}\text { - Lack of funding for } \\
\text { energy-efficiency } \\
\text { programmes } \\
\text { - Unwillingness of banks } \\
\text { to provide lending for } \\
\text { energy-efficiency } \\
\text { projects }\end{array}$} & $\begin{array}{l}\text { - Significant Government } \\
\text { support and close } \\
\text { coordination with the } \\
\text { private sector }\end{array}$ & $\begin{array}{l}\text { - Funds raised by taxing } \\
\text { fossil fuel-based } \\
\text { products (raising about } \\
\text { US } \$ 50 \mathrm{~m} / \text { year) }\end{array}$ \\
\hline & $\begin{array}{l}\text { - An energy-efficiency } \\
\text { policy and institutional } \\
\text { framework }\end{array}$ & \multirow{2}{*}{$\begin{array}{l}\text { - Lines of credit provided } \\
\text { to commercial banks for } \\
\text { energy-efficiency project } \\
\text { lending }\end{array}$} \\
\hline & $\begin{array}{l}\text { - Strong international } \\
\text { strategic support } \\
\text { aligned with government } \\
\text { objectives }\end{array}$ & \\
\hline
\end{tabular}

Financing structure (US\$ millions)

\begin{tabular}{ll|ll}
$\begin{array}{l}\text { Public } \\
\text { investment }\end{array}$ & Sources & $\begin{array}{l}\text { Private } \\
\text { investment }\end{array}$ & Sources \\
\hline Demand side & management plan* & \\
\hline $31.6 \mathrm{~m}$ & $\begin{array}{l}\text { Government of Thailand } \\
\text { (Electricity Generating } \\
\text { Authority) }\end{array}$ & N/A & \\
\hline $14.9 \mathrm{~m}$ & $\begin{array}{l}\text { Grants (GEF, } \\
\text { Government of Australia) }\end{array}$ & & \\
\hline Up to 25 m & $\begin{array}{l}\text { Loan from Japan Bank } \\
\text { for International } \\
\text { Cooperation }\end{array}$ & & \\
\hline Revolving fund for credit lines & & \\
\hline $453 \mathrm{~m}$ & $\begin{array}{l}\text { Total credit lines to } \\
\text { commercial banks as of }\end{array}$ & (estimated) & $\begin{array}{l}\text { Leveraged finance from } \\
\text { comercial banks as of } \\
\end{array}$ \\
& 2010 & & 2010 \\
\hline
\end{tabular}

Total financing mobilized: $\sim 975 \mathrm{~m}$ (estimated)

*Note that not all funding allocated in the demand side management plan has been mobilized.

\section{Achieved leverage}

Public : private leverage Methodology achieved

1:1 Revolving fund credit lines : Financing provided by
participating banks
Lessons learned and scalable attributes

- International support through technical assistance and capacity building is maximized when the goals of government and international partners are aligned.

- Early analysis work by non-governmental organizations highlighted the role of energy efficiency in meeting the country's energy needs.

- Taxes on fossil fuels raised significant funds, giving the Thailand Government a stronger hand when negotiating with international partners.

Carefully allocating risks can attract commercial lenders and private investors: the case of solar water heaters in Tunisia

Case study and data provided by the Climate Policy Initiative and the World Resources Institute ${ }^{101}$

\section{Overview}

In 1996, an initial World Bank-funded project provided a 35\% subsidy on the capital cost of solar water heaters (SWHs) and was successful in stimulating market growth while the funding lasted. The project was not sustainable, however, as other barriers remained. Tunisia's 'programme solaire' (Prosol) was supported by UNEP and the Mediterranean Renewable Energy Programme with US\$2.2 million from the Italian Government in 2005, comprising: US\$1 million for a 20\% subsidy on the capital costs of SWHs; US\$ 1 million for a temporary interest rate subsidy; and US\$ 0.2 million for pre-investment activities to address barriers in the SWH market. The project financing scheme involved providing loans by commercial banks to residential consumers through accredited system suppliers, which were repaid through customers' electricity bills. The Société Tunisienne de l'Electricité et de Gaz (STEG) assumed default risks by acting as the debt repayment enforcer and guarantor of the loans, and passed these risks on to consumers by withholding services in the event of non-payment. In 2007 a second phase was initiated, with the financing mechanisms supported almost exclusively by Tunisian resources, more lending and a wider choice of credit lines to households. By 2010 annual deployment of SWH systems had increased fivefold since the start of the initiative.

\section{Mobilizing private finance}

\begin{tabular}{lll}
$\begin{array}{l}\text { Existing investment } \\
\text { barriers }\end{array}$ & $\begin{array}{l}\text { Underlying enabling } \\
\text { factors }\end{array}$ & $\begin{array}{l}\text { Successful policies and } \\
\text { instruments used }\end{array}$ \\
\hline $\begin{array}{l}\text { - Significant subsidies } \\
\text { on fossil fuels }\end{array}$ & $\begin{array}{c}\text { Early laws to promote } \\
\text { energy conservation }\end{array}$ & $\begin{array}{l}\text { - Capital cost subsidy for } \\
\text { SWH installed in the }\end{array}$ \\
- Lack of available & and awareness & residential sector, \\
financing & promacity building, & eventually provided by \\
- Lack of consumer & etc.) & the utility \\
awareness and & - Careful allocation of & subsidies \\
confidence in the & risks among main actors & - Removing debt default \\
technology & - Affordability for & risk from suppliers \\
& households &
\end{tabular}


Financing structure (US\$ millions)

\begin{tabular}{ll|lll}
$\begin{array}{l}\text { Public } \\
\text { investment }\end{array}$ & Sources & $\begin{array}{l}\text { Private } \\
\text { investment }\end{array}$ & Sources & $\begin{array}{l}\text { Total } \\
\text { investment }\end{array}$ \\
\hline $2.4 \mathrm{~m}$ & $\begin{array}{l}\text { Grant from } \\
\text { Government of } \\
\text { Italy }\end{array}$ & $59.8 \mathrm{~m}$ & $\begin{array}{l}\text { Local commercial } \\
\text { lenders (70\% of } \\
\text { SWH costs) }\end{array}$ & \\
& $\begin{array}{llll}\text { Grant from } \\
\text { Government of } \\
\text { Tunisia }\end{array}$ & $50.3 \mathrm{~m}$ & $\begin{array}{l}\text { Direct payments } \\
\text { for the residual } \\
\text { SWH investment } \\
\text { cost and interest } \\
\text { rates repayments } \\
\text { by end-users }\end{array}$ & \\
& & & & \\
& & & & \\
\hline Total & & $134 \mathrm{~m}$
\end{tabular}

Achieved leverage

Public : private leverage Methodology achieved

1:5 Overall public investment : private investment

\section{Lessons learned and scalable attributes}

- Capacity-building activities targeting financial institutions create awareness for market potential and can be pivotal in engaging local commercial banks to unlock the local credit market. Banks, therefore, can become leading promoters of the sector.

- Carefully allocating risks among the main actors can help attract banks and other private investors.

- Commitment by the Tunisia Government to subsidize SWH investments, to cover the incremental cost of the technology, was crucial in enabling the sector to become competitive when markets are still distorted by fossil-fuel subsidies.

\section{Limited technical assistance can be sufficient to establish an attractive green investment environment: the case of wind energy in Uruguay}

\section{Case study and data provided by UNDP and the Global Environment Facility ${ }^{102}$}

\section{Overview}

A joint project between UNEP and the Global Environment Facility was established between 2007 and 2012 in Uruguay, providing a US\$1 million GEF grant for technical advisory support around policy de-risking measures to address multiple barriers in the energy market. The initiative was designed to support the development of a 5 megawatt demonstration wind project by 2012. The project has exceeded expectations, with 40 megawatts of wind energy now installed. Based on the policies developed using the UNEP-GEF grant funding, a further 880 megawatts of wind-energy contracts are in the pipeline, with a goal of 1 gigawatt to be online in the country by the end of 2015 to provide approximately one-quarter of total national energy consumption. This is a major transition over a short time frame, made possible by rapidly establishing an enabling policy environment that has successfully inspired large financial flows to develop renewable energy. Targeted use of public funding was used to re-disk investments, enabling wind energy to be become a competitive market.

\section{Mobilizing private finance}

\begin{tabular}{lll}
$\begin{array}{l}\text { Existing investment } \\
\text { barriers }\end{array}$ & $\begin{array}{l}\text { Underlying enabling } \\
\text { factors }\end{array}$ & $\begin{array}{l}\text { Successful policies and } \\
\text { instruments used }\end{array}$ \\
\hline $\begin{array}{l}\text { - Lack of national policy } \\
\text { framework for }\end{array}$ & $\begin{array}{c}\text { - UNEP and GEF funding } \\
\text { combined with technical }\end{array}$ & $\begin{array}{c}\text { - US\$1 million GEF grant } \\
\text { renewable energy }\end{array}$ \\
advisory support & $\begin{array}{c}\text { Technical support to } \\
\text { develop policy } \\
\text { de-risking instruments }\end{array}$ \\
- Lack of institutional & & - Technical support to \\
knowledge within & develop a national policy \\
government & framework for \\
- Low awareness of & renewable energy \\
renewable energy & (targets and IPP \\
potential in the country & regulations, etc.) \\
- Technological barriers & - Capacity building to \\
(lack of infrastructure, & raise awareness and \\
equipment and & provide technical \\
expertise) & training (for both the \\
& utility and the Uruguay \\
& Government)
\end{tabular}

Financing structure (US\$ millions)

\begin{tabular}{ll|lll}
$\begin{array}{l}\text { Public } \\
\text { investment }\end{array}$ & Sources & $\begin{array}{l}\text { Private } \\
\text { investment }\end{array}$ & Sources & $\begin{array}{l}\text { Total } \\
\text { investment }\end{array}$ \\
\hline $1 \mathrm{~m}$ & $\begin{array}{l}\text { UNEP-GEF } \\
\text { grants }\end{array}$ & $2,000 \mathrm{~m}$ & $\begin{array}{l}\text { Mobilized } \\
\text { investment to } \\
\text { develop wind energy } \\
\text { (various sources) }\end{array}$ & \\
\hline $6 \mathrm{~m}$ & Co-financing & & & \\
\hline $7 \mathrm{~m}$ & & $2,000 \mathrm{~m}$ & & $\begin{array}{l}2,000 \mathrm{~m} \\
\text { (estimated) }\end{array}$ \\
\hline
\end{tabular}

\section{Achieved leverage}

\begin{tabular}{ll}
$\begin{array}{l}\text { Public : private leverage } \\
\text { achieved }\end{array}$ & Methodology \\
\hline $1: 2000$ & GEF grant : Estimated mobilized investment \\
\hline $1: 285$ & $\begin{array}{l}\text { Overall initial investment : Estimated mobilized } \\
\text { investment }\end{array}$ \\
\hline $1: 6$ & GEF grant : Other co-financing for the initiative \\
\hline
\end{tabular}

\section{Lessons learned and scalable attributes}

- Technical support for policy de-risking can help significantly mobilize investment and create a renewable energy market.

- The case of Uruguay shows that policy de-risking instruments alone can be sufficient to generate a renewable energy market; feed-in tariff incentives were not necessary.

- Transferring technical knowledge to state utilities for procurement, ownership and to operate renewable energy facilities is critical for market scale-up.

- Domestic policy frameworks are crucial to enable a renewable energy market to flourish. Including a national requirement/ target for renewable energy procurement gave the initial required push that created market momentum. 
Public-private fund mechanisms can be self-generating: the case of watershed protection in Ecuador and Columbia

Case study and data provided by the World Water Council ${ }^{103}$

\section{Overview}

The Nature Conservancy set up the Water Funds in Latin America and the Caribbean in 2000. The Water Funds body is an endowment trust that is used to compensate for environmental services, such as supplying clean freshwater and providing biodiversity benefits. Water users (such as municipalities, hydropower facilities and industrial users) pay into the funds in exchange for the product they receive, namely fresh, clean water. The funds pay for forest conservation along rivers, streams and lakes, to ensure safe drinking water is available to all users, rather than being paid directly to individual landowners as in a Payments of Ecosystem Services (PES) scheme. A public-private partnership with various stakeholders, including the water users, determines how the money is allocated to different conservation projects.

There are 13 Water Funds either operating or being developed in Ecuador and Columbia. Initial funding has been provided from various sources, including the Global Environment Facility, the FEMSA Foundation and the Inter-American Development Bank.

Mobilizing private finance

\begin{tabular}{lll}
$\begin{array}{l}\text { Existing investment } \\
\text { barriers }\end{array}$ & $\begin{array}{l}\text { Underlying enabling } \\
\text { factors }\end{array}$ & $\begin{array}{l}\text { Successful policies and } \\
\text { instruments used }\end{array}$ \\
\hline $\begin{array}{l}\text { - Lack of national policy } \\
\text { framework for }\end{array}$ & $\begin{array}{c}\text { - Backing by government } \\
\text { policy and national water }\end{array}$ & - GEF grant funding \\
$\begin{array}{l}\text { conservation and } \\
\text { biodiversity protection }\end{array}$ & management institutions & - Concessional finance \\
from development \\
- Lack of institutional & suppliers and users of & banks \\
knowledge within & ecosystems services & - Payments from water \\
governments & - Good research and & sources) into the fund \\
& information-gathering & \\
& for baseline data and & \\
& monitoring &
\end{tabular}

Financing structure (US\$ millions)

\begin{tabular}{ll|ll}
$\begin{array}{l}\text { Public } \\
\text { investment }\end{array}$ & Sources & $\begin{array}{l}\text { Private } \\
\text { investment }\end{array}$ & Sources \\
\hline $5 \mathrm{~m}$ & GEF grant & $150 \mathrm{~m}$ & $\begin{array}{l}\text { Expected mobilized } \\
\text { investment into the } \\
\text { funds from water users } \\
\text { (various sources) }\end{array}$ \\
\hline $5 \mathrm{~m}$ & FEMSA Foundation & & \\
\hline $20 \mathrm{~m}$ & grant & Inter-American & \\
\hline $30 \mathrm{~m}$ & Development Bank & & \\
\hline
\end{tabular}

Achieved leverage

Public: private leverage Methodology achieved

\begin{tabular}{ll}
\hline $1: 5$ & $\begin{array}{l}\text { Initial mobilizing finance : Estimated mobilized } \\
\text { investment from water users }\end{array}$ \\
\hline
\end{tabular}

Lessons learned and scalable attributes

- Government backing is crucial to successfully establish public-private fund mechanisms.

- Large water users often have adequate private sources of funding that can be used to pay for conservation projects that protect the ecosystem services they rely on.

- Initial grant funding is crucial for project set-up and administration but private sources of investment can lead to eventual high leverage.

- Water users need to commit to pay into the funds to secure the long-term viability of projects.

- Projects work best when there are multiple water users and threats to water availability are high. 


\section{Appendix 3: Relevant Publications}

\section{A. Using public resources to leverage private-sector participation}

Barclays/Accenture

Carbon Capital: Financing the Low Carbon Economy, February 2011; http://group.barclays.com/html_phase_2/assets/docs/ reports/Carbon-Capital_-Financing-the-low-carbon-economy. pdf.

Climate Change Capital

The Green Climate Fund and Private Finance: Instruments to Mobilize Investment in Climate Change Mitigation Projects, 2012; http://www.climatechangecapital.com/media/279342/ thinktank\%20green\%20climate\%20fund.pdf.

\section{Climate Strategies}

Mobilising Private Finance for Low Carbon Development, 2011; http://www.climatestrategies.org/component/reports/ category/71/334.html.

Global Green Growth Institute

The role of public-private cooperation in enabling green growth, 2011; http://www.globalgreengrowthforum.com/fileadmin/user_ upload/3GF_2011_Report_01.pdf.

International Finance Corporation

Climate Finance: Engaging the Private Sector, 2011; http:// www1.ifc.org/wps/wcm/connect/5d659a804b28afee9978f90 8d0338960/ClimateFinance_G20Report.pdf?MOD=AJPERES.

Overseas Development Institute

Leveraging Private Investment: The Role of Public Sector Climate Finance, April 2011; http://www.odi.org.uk/resources/ download/5701.pdf

Japan's Private Climate Finance Support: Mobilising Private Sector Engagement in Low Carbon Development, 2012; http:// www.odi.org.uk/resources/docs/7785.pdf.

The UK's Private Climate Finance Support: Mobilising Private Sector Engagement in Climate Compatible Development: ODI Background Notes, 2012; http://www.odi.org.uk/resources/ docs/7787.pdf.

The United States' Private Climate Finance Support: Mobilising Private Sector Engagement in Climate Compatible Development: ODI Background Notes, 2012; http://www.odi. org.uk/resources/docs/7786.pdf.

Standard \& Poor's

Can Capital Markets Bridge the Climate Change Financing Gap? October 2010; http://www2.standardandpoors.com/spf/pdf/ media/

GlobalEffortsToAddressClimateChangeAreJustWarmingUp.pdf.

\section{United Nations Environment Programme}

Catalyzing low-carbon growth in developing economies: Public Finance Mechanisms to scale up private sector Investment in climate solutions, October 2009; http://www.unep.org/ GreenEconomy/InformationMaterials/Publications/Publication/ tabid/4613/language/en-US/Default.aspx?ID=6156.

REDDy Set Grow: Private Sector Suggestions for International Climate Change Negotiators, 2011; http://www.unepfi.org/ fileadmin/documents/reddysetgrowll.pdf.
World Bank

Development and Climate Change: A Strategic Framework for the World Bank Group, Technical Report, 2008; http://siteresources. worldbank.org/EXTCC/Resources/407863-1219339233881/ DCCSFTechnicalReport.pdf.

World Development Report (Chapter 6)

Generating the Funding Needed for Mitigation and Adaptation; 2010.

\section{B. Types of public financing instruments and mechanisms} Bloomberg New Energy Finance

Crossing the Valley of Death: Solutions to the next generation of clean energy project financing gap, 2010; bnef.com/ WhitePapers/download/29.

\section{Brookings Institution}

The Green Climate Fund: Options for Mobilizing the Private Sector, 2011; http://www.brookings.edu/ /media/Files/rc/ papers/2011/0830_green_climate_fund_sierra/0830_green_ climate_fund_sierra.pdf.

Center for American Progress and the Global Climate Network Leveraging Private Finance for Clean Energy, November 2010; http:// www.americanprogress.org/issues/2010/11/pdf/gcn_memo.pdf

Investing in Clean Energy: How to maximize clean energy deployment from international climate investments, November 2010; http://www.americanprogress.org/issues/2010/11/pdf/ gcnreport_nov2010.pdf.

Climate Policy Initiative

Renewable Energy Financing and Climate Policy Effectiveness, 2011; http://climatepolicyinitiative.org/wp-content/ uploads/2011/12/Renewable-Energy-Financing-and-ClimatePolicy-Effectiveness-Working-Paper.pdf.

Deutsche Bank Group

GET Fit Program: Global Energy Transfer Feed in Tariffs for Developing Countries, April 2010; http://www.dbcca.com/ dbcca/EN/_media/GET_FiT_Program.pdf.

GET FiT Plus: DE-Risking Clean Energy Business Models in a Developing Country Context, April 2011; http://www.dbcca.com/ dbcca/EN/_media/GET_FiT_Plus. pdf?dbiquery=null\%3AGET+FiT.

Frankfurt School - UNEP Collaborating Center for Climate and Sustainable Energy Finance

Case Study: The Thai Energy Efficiency Revolving Fund, 2012; http://fs-unep-centre.org/sites/default/files/publications/ fs-unepthaieerffinal2012_0.pdf.

G20 / International Finance Corporation

Climate Finance: Engaging the Private Sector. A background paper for Mobilizing Climate Finance, a report prepared at the request of G20 Finance Ministers; http://www1.ifc.org/wps/ wcm/connect/5d659a804b28afee9978f908d0338960/ ClimateFinance_G20Report.pdf?MOD=AJPERES.

\section{GCCC (Global Climate Change Consultancy)}

Engaging Private Sector Capital at Scale in Financing Low Carbon Infrastructure in Developing Countries, May 2010; http:// www.gtriplec.co.nz/assets/Uploads/papers/engaging_private_ sector_capital_at_scale_2010_11_15.pdf 


\section{GIZ}

Smart Climate Finance: Designing Public Finance Strategies to Boost Private Investment in Developing Countries, 2011; http:// www2.gtz.de/dokumente/bib-2011/giz2011-0233en-smartclimate-finance.pdf.

Global Financial Mechanism Project (an initiative of WWF)

Global Financial Mechanism Project: Proposals for the Design and Operation of a UNFCCC to Support At-Scale Mitigation Developing Countries and Leverage Additional Public and Private Sources of Funding, June 2010; http://

climateregistryoption.org.

International Energy Agency

Joint Public-Private Approaches for Energy Efficiency Finance: Policies to Scale Up Private Sector Investment, 2012; http:// www.iea.org/publications/freepublications/publication/finance-1. pdf.

\section{The Oxford Institute for Energy Studies}

Mobilizing the Private Sector: Quantity-Performance Instruments for Public Climate Funds, 2012; http://www.oxfordenergy.org/ wpcms/wp-content/uploads/2012/08/Mobilizing-the-PrivateSector.pdf.

\section{San Giorgio Group}

Case Studies on Ouarzazate I Concentrated Solar Power (Morocco), Prosol (Tunisia), and Walney Offshore Wind Farms (United Kingdom), 2012; http://climatepolicyinitiative.org/ publication/san-giorgio-group-case-studies/.

UNEP Risoe Center on Energy, Climate and Sustainable Development

Accessing International Financing for Climate Change Mitigation, 2012; http://tech-action.org/Guidebooks/TNA_Guidebook_ MitigationFinancing.pdf.

United Nations

Global Trends in Sustainable Energy Investment (Released Annually); http://sefi.unep.org/english/globaltrends2010.html.

Public Finance Mechanisms to mobilize private sector investment in climate change mitigation, 2008; http://www.sefi. unep.org/fileadmin/media/sefi/docs/UNEP_Public_Finance_ Report.pdf.

Investing in a Climate for Change: Engaging the Finance Sector, 2008; http://www.uneptie.org/energy/information/publications/ details.asp?id=WEB/0140/PA.

Private Financing of Renewable Energy - A Guide for Policy Makers, 2009; http://www.uneptie.org/energy/finance/pdf/ Finance_guide\%20FINAL.pdf.

Publicly Backed Guarantees as a Policy Instrument to Back Clean Energy, 2010; http://www.uneptie.org/energy/finance/pdf/ guarantees_web.pdf.

\section{United Nations Development Programme}

Blending Climate Finance through National Climate Funds, 2011; http://www.undp.org/content/dam/undp/library/ Environment\%20and\%20Energy/Climate\%20Change/ Capacity\%20Development/Blending_Climate_Finance_ Through_National_Climate_Funds.pdf.
United Nations Economic Commission for Europe

Financing Global Climate Change Mitigation, 2010; http://www. unece.org/fileadmin/DAM/energy/se/pdfs/gee21/gee21_pub/ GEE21_GlobalClimateChangeMitigation_ESE37.pdf.

\section{United Nations Environment Programme}

Innovative Climate Finance: Examples from the UNEP Bilateral Finance Institutions Climate Change Working Group, 2011; http://www.unep.org/pdf/UNEP_Innovative_climate_finance_ final.pdf.

United Nations Environment Programme - Finance Initiative

Financing renewable energy in developing countries: drivers and barriers for private finance in sub-Saharan Africa, 2012; http:// www.unepfi.org/fileadmin/documents/Financing_Renewable_ Energy_in_subSaharan_Africa.pdf.

\section{World Bank}

Mobilizing Climate Finance, 2011; http://www.g20-g8.com/ g8-g20/root/bank_objects/G20_Climate_Finance_report.pdf.

World Resources Institute

Public Financing Instruments to Leverage Private Capital for Climate-Relevant Investment: Focus on Multilateral Agencies, 2012; http://www.wri.org/publication/public-financeinstruments-to-leverage-private-capital-for-climate-investment.

Moving the Fulcrum: A Primer on Public Climate Financing Instruments Used to Leverage Private Capital, 2012; http://www. wri.org/publication/moving-the-fulcrum.

\section{Other contextual publications}

\section{Ceres and UN Foundation}

Investor Summit on Climate Risk and Energy Solutions - Final Report, 2012; http://www.ceres.org/resources/reports/2012investor-summit-on-climate-risk-energy-solutions-final-report/ view.

\section{Climate Investment Funds}

CIF from the Ground Up: Investing in our Green Future, 2011; http://www.climateinvestmentfunds.org/cif/sites/ climateinvestmentfunds.org/files/CIF_Annual_Report.pdf.

Climate Policy Initiative

Public Climate Finance: A Survey of Systems to Monitor and Evaluate Climate Finance Effectiveness, 2012; http:// climatepolicyinitiative.org/wp-content/uploads/2012/07/ Public-Climate-Finance-Survey.pdf.

Improving the Effectiveness of Climate Finance: A Survey of Leveraging Methodologies, 2011; http://www.edf.org/sites/ default/files/effectiveness-\%20climate-finance-leveragingmethodologies.pdf.

Global Landscape of Climate Finance, 2012; http:// climatepolicyinitiative.org/wp-content/uploads/2012/12/ The-Landscape-of-Climate-Finance-2012.pdf.

Effective Green Financing: What have we learned so far? 2012; http://climatepolicyinitiative.org/wp-content/uploads/2012/12/ Effective-Green-Financing-What-have-we-learned-so-far.pdf.

Conference on Trade and Development

World Investment Report: Investing in a Low Carbon Economy, 2010; http://unctad.org/en/docs/wir2010_en.pdf. 


\section{European Investment Bank}

Investment and Growth in the Time of Climate Change, 2012; http://www.eib.org/attachments/thematic/investment_and_ growth_in_the_time_of_climate_change_en.pdf.

Friends of the Earth

The Green Climate Fund's "No-Objection” Procedure and Private Finance: Lessons Learned from Existing Institutions, 2012; http://libcloud.s3.amazonaws.com/93/21/8/2350/no_obj_ reprt_foe_gaia_ips_FINAL_8-10.pdf.

Global Environment Facility

Behind the Numbers: A closer look at GEF achievements, 2012; http://www.thegef.org/gef/sites/thegef.org/files/publication/ GEF_Behind_the_Numbers_CRA.pdf.

Global Green Growth Institute

Press Release, "Global Organizations to Expand Cooperation on Green Growth for Development” Jan 11, 2012, Mexico City; http://www.oecd.org/dataoecd/60/48/49379356.pdf.

Grantham Institute

A strategy for restoring confidence and economic growth through green investment and innovation, 2012; http://www2. Ise.ac.uk/Granthamlnstitute/publications/Policy/docs/PBZenghelis-economic-growth-green-investment-innovation.pdf. HSBC

Sizing the Climate Economy, 2010; http://www.research.hsbc.com/ midas/Res/RDV?ao=20\&key=wU4BbdyRmz\&n=276049.PDF.

International Finance Corporation

Doing Business 2011: Making a Difference for Entrepreneurs, 2011; http://www.doingbusiness.org/reports/global-reports/ doing-business-2012.

\section{McKinsey \& Co}

Resource Revolution: Meeting the world's energy, materials, food and water needs, 2011; http://www.mckinsey.com/ Features/Resource_revolution.

Organisation for Economic Co-operation and Development

Buchner B., Brown J. and Corfee Morlot, J., (2011), "Monitoring and tracking long term finance to support climate action," OECD Publishing/IEA, Paris; www.oecd.org/dataoecd/57/57/48073739.pdf.

Corfee-Morlot, J. et al (2012), "Toward a Green Investment Policy Framework: The Case of Low-Carbon, Climate-Resilient Infrastructure", Environment Directorate Working Papers, No. 48, OECD Publishing, Paris; http://www.oecd-ilibrary.org/ environment/towards-a-green-investment-policyframework_5k8zth7s6s6d-en.

Kaminker, C, Stewart, F. (2012), "The Role of Institutional Investors in Financing Clean Energy", OECD Working Papers on Finance, Insurance and Private Pensions, No. 23, OECD Publishing, Paris; http://www.oecd.org/daf/financialmarketsinsuranceandpensions/ privatepensions/WP_23

TheRoleOfInstitutionallnvestorsInFinancingCleanEnergy.pdf.

The Role of Institutional Investors in Financing Clean Energy, 2012; http://www.oecd-ilibrary.org/finance-and-investment/ the-role-of-institutional-investors-in-financing-cleanenergy_5k9312v2116f-en.

Financing Climate Change Action brochure, 2012; http://www. oecd.org/env/climatechange/Financing\%20Climate\%20 Change\%20brochure.pdf
Pew Environmental Group / Bloomberg New Energy Finance

Who's winning the clean energy race? 2011 Edition; http://www. pewenvironment.org/news-room/reports/whos-winning-theclean-energy-race-2011-edition-85899381106

Renewable Energy Policy Network for the 21st Century

Renewables 2011 Global Status Report, 2011; http://www.ren21. net/Portals/97/documents/GSR/REN21_GSR2011.pdf.

Stockholm Environment Institute

Will Private Finance Support Climate Change Adaptation in Developing Countries? 2011; http://www.sei-international.org/ mediamanager/documents/Publications/Climate/SEI-WP-201105-Private-Sector-Adaptation-Finance-ES.pdf.

United Nations Development Programme

Transforming On-Grid Renewable Energy Markets: A Review of UNDP-GEF Support for Feed-in Tariffs and Related Price and Market-Access Instruments, 2012; http://www.undp.org/ content/dam/undp/library/Environment\%20and\%20Energy/ Climate\%20Strategies/UNDP_FIT_Port_ TransformingREMarkets_15oct2012.pdf

United Nations - AGF

Report of the Secretary-General's High-Level Advisory Group on Climate Change Financing, November 2010; http://www.un org/wcm/webdav/site/climatechange/shared/Documents/ AGF_reports/AGF\%20Report.pdf.

United Nations Environment Programme

Towards a Green Economy: Pathways to Sustainable Development and Poverty Eradication, 2011; http://www.unep. org/greeneconomy/Portals/88/documents/ger/ger_final_ dec_2011/Green\%20EconomyReport_Final_Dec2011.pdf.

United Nations Environment Programme - Finance Initiative (with IIGCC, INCR, and IGCC)

Investment-grade climate change policy: financing the transition to the low-carbon economy, 2011; http://www.unepfi.org/ fileadmin/documents/Investment-GradeClimateChangePolicy. pdf.

\section{World Economic Forum}

Financing Green Growth in a Resource-constrained World, 2011; http://www.weforum.org/reports/financing-green-growthresource-constrained-world.

Green Investing 2011: Reducing the Cost of Financing; http:// europa.eu/epc/pdf/workshop/3-1_bnef-wef_greeninvesting_ report_2011_en.pdf.

Green Investing 2010: Policy Mechanisms to Bridge the Financing Gap; https://members.weforum.org/pdf/climate/ greeninvesting2010.pdf.

World Economic Forum: Critical Mass Initiative

Critical Mass Initiative Working Report: Scaling Up Low Carbon Infrastructure Investments in Developing Countries, January 2011; http://europa.eu/epc/pdf/workshop/3-1_wef_ei_ criticalmass_report_2011_en.pdf. 


\section{References}

Bloomberg New Energy Finance Asset Finance Database,
2012.

OECD (2006), Infrastructure to 2030: Telecom, Land Transport, Water and Electricity, OECD Publishing.

OECD (2012), Strategic Transport Infrastructure Needs to 2030, OECD Publishing.

Energy Technology Perspectives, 2012, IEA.

5. Capital Requirements for Agriculture in Developing Countries to 2050, 2009, FAO; http://www.fao.org/fileadmin/templates/esa/ Global_persepctives/Long_term_papers/Capitalrequirements-agriculture.pdf.

6. Forests in a Green Economy: A Synthesis, 2011, UNEP; http:// www.unep.org/pdf/PressReleases/UNEP-ForestsGreenECObasse def version normale.pdf.

Social Cohesion: Making it happen, 2011, OECD; http:// oecdinsights.org/2011/11/21/social-cohesion-making-ithappen. 8. OECD Environmental Outlook to 2050, OECD; www.oecd.org/
environment/outlookto2050.

9. Energy Technology Perspectives, 2012, IEA

10. Washington Post, 31 October 2012; http://business.time. com/2012/10/31/hurricane-sandy-estimated-to-cost-60-billion.

1. Driving to 54.5 MPG: The history of fuel economy, PEW, 2011; http://www.pewenvironment.org/news-room/fact-sheets/
driving-to-545-mpg-the-history-of-fuel-economy-329037.

12. Global Trends in Renewable Energy Investment, 2012, United Collaborating Centre for Climate \& Sustainable Energy Finance and Bloomberg New Energy Finance; http://www.bnef.com/

13. Q2 2012 Clean Energy Policy and Market Briefing, 19 July 2012, Bloomberg New Energy Finance; http://www.bnef.com/ WhitePapers/view/114

14. Progress on Drinking Water and Sanitation, 2012 Update, 2012, UNICEF and WHO; http://www.unicef.org/media/files/ JMPreport2012.pdf.

15. Forests in a Green Economy: A Synthesis, 2011, UNEP; http:// www.unep.org/pdf/PressReleases/
basse_def_version_normale.pdf.

16. Stern Review on the Economics of Climate Change, 2006.

17. Energy Technology Perspectives, 2012, IEA

18. Inderst, G, Kaminker, C, Stewart, F. (2012) “Defining and Measuring Green Investments: Implications for Institutional Investors' Asset Allocations", OECD Working Papers on
Finance, Insurance and Private Pensions, No. 24, OECD Finance, Insurance
Publishing, Paris.

19. UNSG High-level Panel on Sustainability; http://www.un.org/ gsp/

20. For a review of development capital investment needs for green growth, see Carbon Capital: Financing the low carbon economy, 2011, Accenture and Barclays.

21. Turn Down the Heat: Why a 4 degree centigrade warmer world must be avoided, World Bank, 2012; http://climatechange. worldbank.org/sites/default/files/Turn_Down_the_heat_. Why a 4 degree centrigrade_warmer_world must be avoided.pdf.

22. Resource Revolution: Meeting the world's energy, materials, food and water needs, McKinsey Global Institute, 2011; http:// www.mckinsey.com/insights/mgi/research/natural_resources/ resource_revolution.

23. OECD (2006), Infrastructure to 2030: Telecom, Land Transport, Water and Electricity, OECD Publishing.

24. OECD (2012), Strategic Transport Infrastructure Needs to 2030 , OECD Publishing.

25. Energy Technology Perspectives, 2012, IEA.

26. Forests in a Green Economy: A Synthesis, 2011, UNEP; http:// www.unep.org/pdf/PressReleases/
basse def_version_normale.pdf.

27. Capital Requirements for Agriculture in Developing Countries to 2050, 2009, FAO; http://www.fao.org/fileadmin/templates/esa/ Global_persepctives/Long_term_papers/Capitalrequirements-agriculture.pdf.

28. Study: Global infra spend to miss OECD estimates, January 2011, Infrastructure Investor Online; http://www. infrastructureinvestor.com/Article.aspx?article=58941\&hashID

9. Energy Technology Perspectives, 2012, IEA

.

30. Corfee-Morlot, J et al (2012), "Toward a Green Investment Policy Framework: The Case of Low-Carbon, Climate-Resilient Infrastructure", Environment Directorate Working Papers, No. 48, OECD Publishing, Paris

31. OECD (2006), Infrastructure to 2030: Telecom, Land Transport, Water and Electricity, OECD Publishing

32. OECD (2012), Strategic Transport Infrastructure Needs to 2030, OECD Publishing.

33. Energy Technology Perspectives, 2012, IEA.

34. Capital Requirements for Agriculture in Developing Countries to

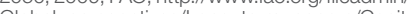
/Capital-

35. Forests in a Green Economy: A Synthesis, 2011, UNEP; http:// www.unep.org/pdf/PressReleases/UNEP-ForestsGreenEco-
basse_def_version_normale.pdf.
36. Capital Requirements for Agriculture in Developing Countries to 2050, 2009, FAO; http://www.fao.org/fileadmin/templates/esa Global_persepctives/Long_term

37. Data from 2005, ASTI, available at http://www.asti.cgiar.org

38. OECD (2006), Infrastructure to 2030: Telecom, Land Transport, Water and Electricity, OECD Publishing.

39. Working Group II Report "Impacts, Adaptation and Vulnerability", IPCC Fourth Assessment Report, 2007, IPCC; fourth $/$ www.ipcc.ch/publications_and_data/publications_ipcc and_vulnerability.htm.

40. Economics of Adaptation to Climate Change: Synthesis Report 2010, World Bank; http://siteresources.worldbank.org/EXT

41. Turn Down the Heat: Why a 4 degree centigrade warmer world must be avoided, World Bank, 2012; http://climatechange. worldbank.org/sites/default/files/Turn_Down_the_heat_ Why_a_4_degred.

42. Global Landscape of Climate Finance, 2012, Climate Policy Initiative; http://climatepolicyinitiative.org/wp-content/ uploads/2012/12/The-Landscape-of-Climate-Finance-2012. pdf.

43. Energy Technology Perspectives, 2012, IEA

44. Energy Technology Perspectives, 2012, IEA

45. Energy Technology Perspectives, 2012, IEA.

46. Energy Technology Perspectives, 2012, IEA

47. Energy Technology Perspectives, 2012, IEA.

48. State of the world's forest 2009, FAO; http://www.fao.org/ docrep/011/i0350e/i0350e00.htm.

49. The Global Alliance for Clean Cookstoves; http://www. cleancookstoves.org/our-work/the-issues/.

50. Global Landscape of Climate Finance, 2012, Climate Policy Initiative; http://climatepolicyinitiative.org/wp-content/ uploads/2012/12/The-Landscape-of-Climate-Finance-2012 pdf.

51. Global Landscape of Climate Finance, 2012, Climate Policy Initiative; http://climatepolicyinitiative.org/wp-content/ uploads/2012/12/The-Landscape-of-Climate-Finance-2012. pdf.

52. Bloomberg New Energy Finance Asset Finance Database

53. Who's winning the clean energy race? 2011 Edition, 2011, Bloomberg New Energy Finance and PEW; http://www. pewenvironment.org/news-room/reports/whos-winning-the-
clean-energy-race-2011-edition-85899381106

54. Q2 2012 Clean Energy Policy and Market Briefing, 19 July 2012, Bloomberg New Energy Finance; http://www.bnef.com/ WhitePapers/view/114.

55. Energy Technology Perspectives, 2012, IEA.

56. Bloomberg New Energy Finance Asset Finance Database, 2012.

57. Bloomberg New Energy Finance Asset Finance Database,

58. Bloomberg New Energy Finance Asset Finance Database, 2012. 59. Global Landscape of Climate Finance, 2012, Climate Policy
Initiative; http://climatepolicyinitiative.org/wp-content/ uploads/2012/12/The-Landscape-of-Climate-Finance-2012. pdf.

60. Bloomberg New Energy Finance Asset Finance Database, 2012.

61. Global Landscape of Climate Finance, 2012, Climate Policy Initiative; http://climatepolicyinitiative.org/wp-content/ uploads/2012/12/The-Landscape-of-Climate-Finance-2012 pdf.

62. Global Landscape of Climate Finance, 2012, Climate Policy Initiative; http://climatepolicyinitiative.org/wp-content/ uploads/2012/12/The-Landscape-of-Climate-Finance-2012 pdf.

63. Bloomberg New Energy Finance Summit, March 2012, Keynote Presentation, http://bnefsummit.com/images/file-upload/ BNEF_2012-03-20-ml_keynote.pd

64. Moving the Fulcrum: A primer on public climate financing instruments used to leverage private capital (Working Paper) 2012, World Resources Institute; http://www.wri.org/ publication/moving-the-fulcrum.

65. See OPIC website for more details: http://www.opic.gov/ what-we-offer/political-risk-insurance/types-of-coverage/ regulatory-risk.

66. Brookings Blog Post: Message for Durban: Scale-up through a Green Climate Fund Private Sector Facility, 2011, Sierra, Katherine; http://www.brookings.edu/research/ opinions/2011/11/28-durban-sierra.

67. Japan's private climate finance support: mobilising private sector engagement in climate compatible development, 2012 sector engagement in climate compatible development,
Overseas Development Institute; http://www.odi.org.uk/ publications/6238-japan-private-climate-finance-low-carbonpublication.
growth.

68. Position paper on leverage of public and private funds, 2012, IDFC; http://www.idfc.org/Downloads/Position_Paper_on

9. Public Financing Instruments to Leverage Private Capital for Climate-Relevant Investment: Focus on Multilateral Agencies."
November 2012. WRI Working Paper, World Resources Institute November 2012. WRI Working Paper, World Resources Insti
http://www.wri.org/project/climate-finance-private-sector.

2012 Bonds and Climate Change, The State of the Market, 2012, Climate Bond Initiative and HSBC; http://climatebonds net/wp-content/uploads/2012/05/CB-HSBC_Final_30May12Single.pdf.

1. Donor Nations Pledge Over \$6.1 Billion to Climate Investment Funds, News Release, 26th September 2008; http://go. worldbank.org/36H73DPMVO.

72. Data available at: https://www.climateinvestmentfunds.org/cif/ node/2.
. Climate Investment Funds, Quarterly Report, September 2012; https://www.climateinvestmentfunds.org

74. Available at: https://www.climateinvestmentfunds.org/cif/ node/3.

. 2012 Bonds and Climate Change, The State of the Market, 2012, Climate Bond Initiative and HSBC; http://climatebonds. net/wp-content/uploads/2012/05/CB-HSBC_Final_30May12Single.pdf.

76. OECD (2012), Financing Climate Change Action brochure http://www.oecd.org/env/climatechange//Financing\%20 Climate $\% 20$ Change $\% 20$ brochure.pdf. \$86bn is a composite
figure comprised of the $\$ 16 \mathrm{bn}$ officially provided as the OECD estimate of 'green bonds' and including the $\$ 70$ bn estimated to have been raised by 'green' corporate bonds excluded from their definition.

77. Kaminker, C, Stewart, F (2012), "The Role of Institutional Investors in Financing Clean Energy", OECD Working Papers on Finance, Insurance and Private Pensions, No. 23, OECD Publishing, Paris.

78. For more information of usage in wind energy markets in India, see: Ghosh et al. (2012); http://www.oxfordenergy.org/wpcms/ pdf

79. Global Landscape of Climate Finance, 2012, Climate Policy Initiative; http://limatepolicyinitiative.org/wp-content/ uploads/2012/12/The-Landscape-of-Climate-Finance-2012. pdf.

80. Mobilizing Climate Investment: The role of international climate finance in creating readiness for scaled-up low-carbon energy (forthcoming), World Resources Institute.

81. Climate Finance: Annotated Questions Document, Draft, 2012 OECD

82. Report of the Secretary-General's High-level Advisory Group on Climate Change Financing, 2010, UNSG AGF; http://www. un.org/wcm/content/site/climatechange/pages/ financeadvisorygroup/pid/13300.

83. Improving the Effectiveness of Climate Finance: A Survey of Leveraging Methodologies, 2011, Climate Policy Initiative; http:/ Leveraging Methodologies, 2011, Climate Policy Initiative
climatepolicyinitiative.org/publication/improving-theeffectiveness-of-clima-finance-key-lessons/.

84. Climate Finance: Engaging the Private Sector, 2011, IFC; http:// www1.ifc.org/wps/wcm/connect/topics_ext_content/ifc external_corporate_site/cb_home/publications/publication

Climateln

. Climate Investment Funds Website; https:// climateinvestmentfunds.org/cif/.

86. CDM Pipeline, 2012, UNEP Risoe, http://www.cdmpipeline.org.

87. State and Trends of the Carbon Market 2012, The World Bank http://siteresources.worldbank.org/INTCARBONFINANCE/ Resources/State ar

88. Is there a leverage paradox within climate finance? 2011, Climate Strategies; http://www.climatestrategies.org/ component/reports/category/71/324.html.

89. CDM Pipeline, 2012, UNEP Risoe, http://www.cdmpipeline.org

90. Global Landscape of Climate Finance, 2012, Climate Policy Initiative; http://climatepolicyinitiative.org/wp-content/ uploads/2012/12/The-Landscape-of-Climate-Finance-2012. pdf.

. The 2012 APEC Leaders' Statement and the APEC List of Environmental goods can be found at: http://www.apec.org/
Meeting-Papers/Leaders-Declarations/2012/2012 aelm.aspx.

2. Energy Technology Perspectives, 2012, IEA.

93. OECD (2006), Infrastructure to 2030: Telecom, Land Transport, Water and Electricity, OECD Publishing

94. OECD (2012), Strategic Transport Infrastructure Needs to 2030 OECD Publishing.

95. Capital Requirements for Agriculture in Developing Countries to 2050, 2009, FAO; http://www.fao.org/fileadmin/templates/esa Global_persepctives/Long_term_papers/Capital-

96. Forests in a Green Economy: A Synthesis, 2011, UNEP; http:// www.unep.org/pdf/PressReleases/UNEP-ForestsGreenECObasse_def_version_normale.pdf

97. Francke, E, Macías, J, Schmid, G(2012)، "The Mobilisation of Private Investment for Low-carbon, Climate-Resilient Infrastructure: The Case of Metrobus Bus Rapid Transit System in Mexico City", draft case study prepared for the OECD by CTS EMBARQ Mexico, http://www.oecd.org/env/climatechange/ Case\%20study\%20Mexico.pdf

98. San Giorgio Group Case Study: Walney Offshore Windfarms, 2012, Climate Policy Initiative: http://climatepolicyinitiative.org/ publication/san-giorgio-group-case-studies/.

99. San Giorgio Group Case Study: Ourarzazate I, 2012, Climate Policy Initiative; http://climatepolicyinitiative.org/publication/ san-giorgio-group-case-studies/.

100. Mobilizing Climate Investment: The role of international climate finance in creating readiness for scaled-up low-carbon energy (forthcoming). World Resources Institute.

101. San Giorgio Group Case Study: Prosol Tunisia, 2012, Climate Policy Initiative; http://climatepolicyinitiative.org/publication/ san-giorgio-group-case-studies/.

102. Transforming On-Grid Renewable Energy Markets, 2012 UNDEP and GEF; http://web.undp.org/gef/document/UNDP FIT_Port_TransformingREMarkets_15oct2012.pdf.

103. Water and Green Growth, Edition I, 2012, World Water Council; http://www.worldwatercouncil.org/fileadmin/wwc/ Library/Publications_and_reports/2.Green_Growth_Report Edition1.pdf. 


\section{Green Growth Action Alliance Members}

The Green Growth Action Alliance is supporting the scale-up in green growth through the collaboration of more than 50 leading financial institutions, corporations, governments and nongovernmental organizations. By bringing together the knowledge of many different stakeholders, the Alliance aims to work with governments to help them adopt a systematic approach that rewards innovative green sectors through sound policies and improves their access to finance. Alliance members aim to achieve this by: collaborating to identify and deploy public money that can be used to unlock and utilize private-sector investment; identifying innovative financing and de-risking structures; supporting pilot testing of new models; and sharing results with international processes.
Accenture

Alcatel-Lucent

Applied Materials

Bank of America Merrill Lynch

Barclays Capital

Black Sea Trade and Development Bank

Climate Development Knowledge

Network

Climate Policy Initiative

Deutsche Bank Group

Environmental Defense Fund

Eskom Holdings

European Bank for Reconstruction and

Development

European Investment Bank

FEMSA

GDF Suez

GE Energy

Global Green Growth Forum

Global Green Growth Institute

Grupo Financiero Banorte

Hanwha Group

$\mathrm{HSBC}$

Iberdrola

Infosys

Inter-American Development Bank

International Centre for Trade and

Sustainable Development

Japan International Cooperation Agency

KfW Bankengruppe
McKinsey \& Company

Morgan Stanley

Nacional Financiera SNC

Novozymes

Organisation for Economic Co-operation and Development

Overseas Private Investment Corporation

Private Sector Center for Sustainable

Development Studies

Samsung Electronics Company

Sekunjalo Investments

Siemens

Standard Chartered Bank

Standard \& Poor's

Suntech Power

Suzlon Energy

Swiss Reinsurance Company

Thomson Reuters

Trina Solar

United Nations Environment Programme Finance Initiative

United Nations Foundation

Vestas Wind Systems

Wal-Mart Stores

Welspun Energy

World Bank Group

World Resources Institute

World Trade Organization

Yara International

Zurich Insurance Group 


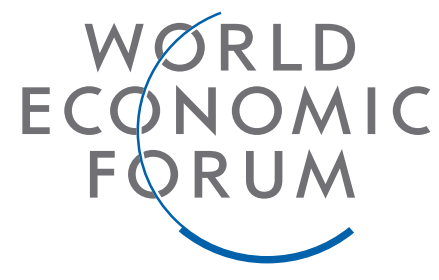

COMMITTED TO

IMPROVING THE STATE

OF THE WORLD

The World Economic Forum is an independent international organization committed to improving the state of the world by engaging business, political, academic and other leaders of society to shape global, regional and industry agendas.

Incorporated as a not-for-profit foundation in 1971 and headquartered in Geneva, Switzerland, the Forum is tied to no political, partisan or national interests 